\title{
JULIET BULL
}

\section{THE IMPLICATIONS OF A SUPREME LAW BILL OF RIGHTS FOR JUDICIAL APPOINTMENTS IN NEW ZEALAND}

SUBMITTED FOR THE LLB (HONOURS) DEGREE LAWS 522: JUDICIARY

FACULTY OF LAW

TE WHARE WĀNANGA O TE ŨPOKO O TE IKA A MĀUI

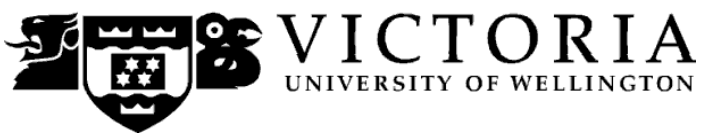

2014 


\section{Table of Contents}

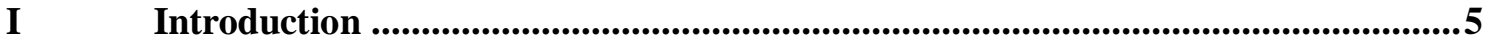

II A Supreme Law Bill of Rights For New Zealand .....................................................6

A New Zealand Bill of Rights Act 1990 ........................................................................ 6

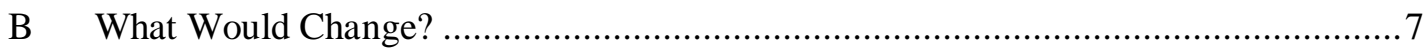

C The Politicisation of Judicial Appointments ......................................................... 10

III Present System of Judicial Appointments ................................................................13

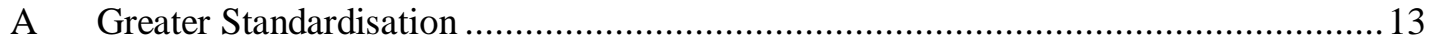

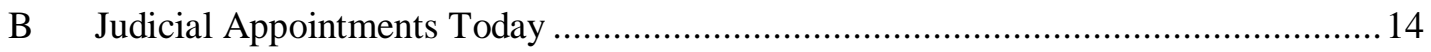

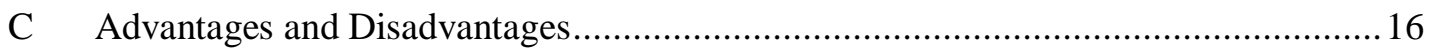

1 Strength of the Constitutional Convention ................................................ 18

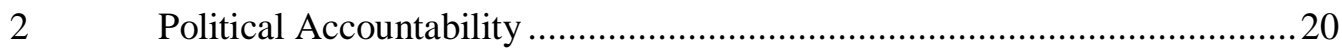

IV Is The Present System Suitable? Canada's Experience .......................................22

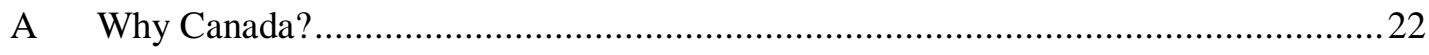

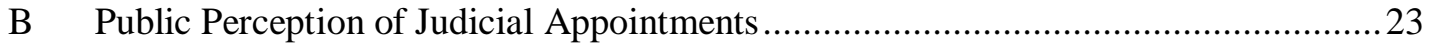

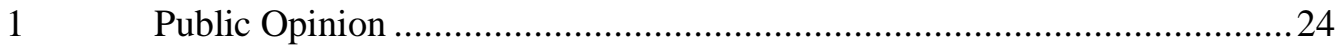

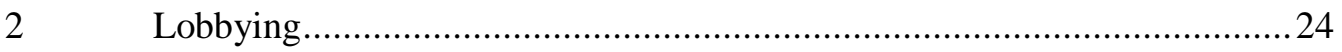

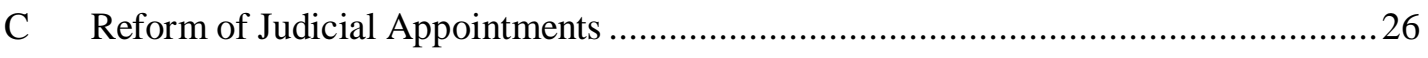

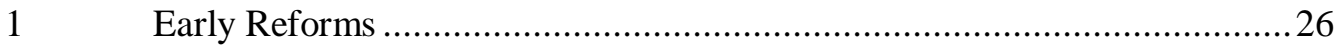

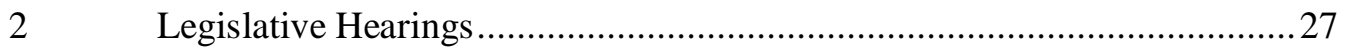

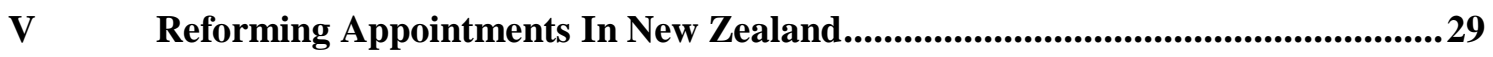

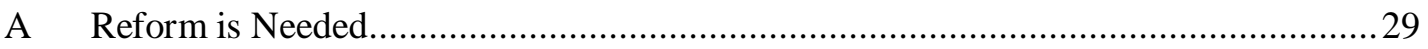

B Character of the Necessary Reform ….................................................................. 31

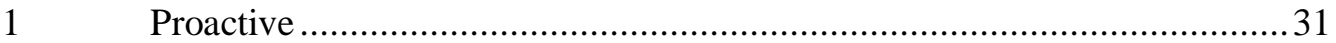

2 Codified

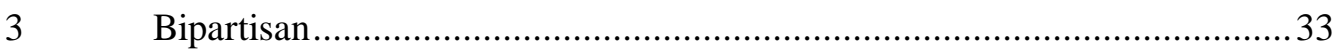

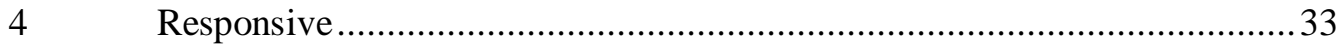

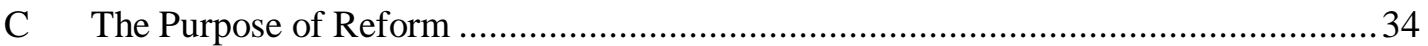


VI Options For Reform ..........................................................................................36

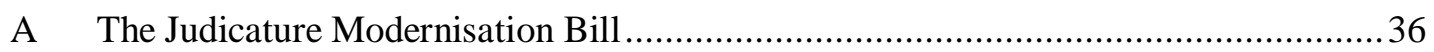

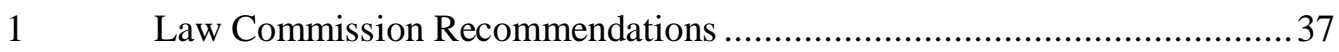

2 Inadequacy of the Judicature Modernisation Bill..................................... 38

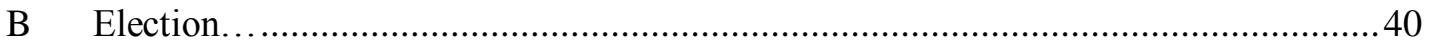

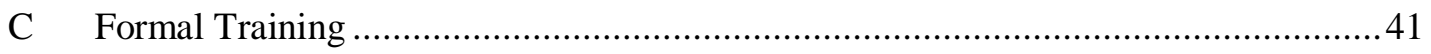

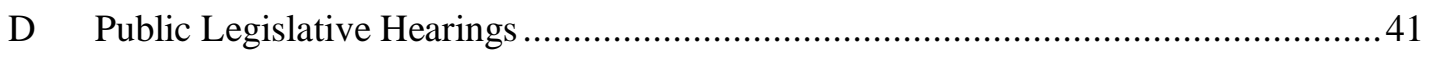

VII Private Confirmation ...............................................................................................42

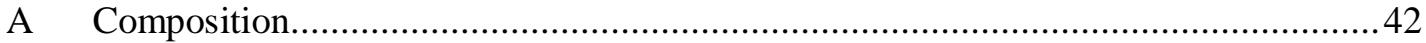

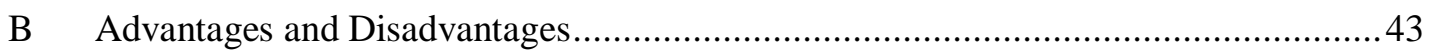

VIII Appointments Commission .................................................................................44

A Appointing or Recommending Commission …...................................................45

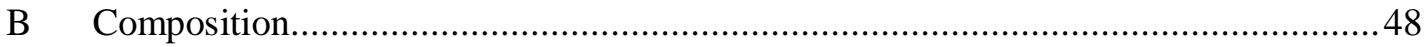

$1 \quad$ Political Appointments to the Commission ...........................................48

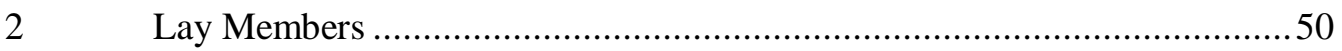

$3 \quad$ Members of Parliament ...................................................................... 51

C The Case for an Appointments Commission …....................................................52

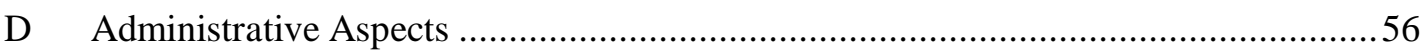

IX Conclusion ............................................................................................................................5

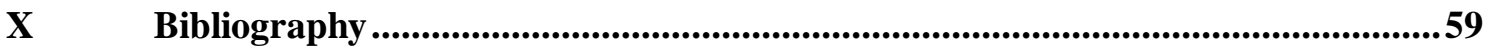




\begin{abstract}
The enactment of a supreme law Bill of Rights in New Zealand would have significant implications for the process of appointing judges. This essay contends that the present judicial appointments system is insufficiently transparent and offers too few safeguards to prevent judicial appointments from becoming politicised. It draws on Canada's experience after enacting the Canadian Charter of Rights and Freedoms to illustrate why reform is needed. Ultimately, it is contended that the adoption of a supreme law Bill of Rights in New Zealand should be accompanied by the creation of a judicial appointments commission.
\end{abstract}

\title{
Word Length
}

The text of this paper (excluding abstract, table of contents, footnotes and bibliography) comprises 14,996 words.

\section{Subject}

Bill of Rights

Judicial appointments

Appointments commission 


\section{Introduction}

The enactment of a supreme law Bill of Rights Act (BORA) would have significant implications for New Zealand's system of appointing judges. At present, judges cannot strike down legislation as the New Zealand Bill of Rights Act 1990 is an ordinary statute that is not supreme to other laws. If this were changed, judges would be able to invalidate legislation which was inconsistent with fundamental rights and freedoms. This would make the judiciary a more powerful branch of government and would involve judges more prominently in political and policy disputes, increasing the incentive for governments to improperly appoint judges based on political factors.

The adoption of a supreme law BORA would therefore raise significant questions about the process by which judges are appointed. This paper examines whether the present appointments system is sufficiently transparent and democratic and whether it would effectively safeguard judicial independence once judges become the final arbiters of rights-based disputes.

The first part of this paper sets out how the role of judges would be altered by a supreme law BORA and, in particular, what is meant by the oft-stated charge that judicial appointments will subsequently become politicised. It then examines New Zealand's present system of appointments, where the Attorney-General is responsible for selecting judges. The integrity of key actors is shown to be the main safeguard against improperly political appointments.

Drawing on Canada's experience after the Canadian Charter of Rights and Freedoms (the Charter) was enacted, this paper then contends that the existing appointments system should not be retained if a supreme law BORA is adopted. The present process lacks transparency and provides insufficient safeguards to ensure public confidence in the political neutrality of appointments. The Canadian experience provides several conclusions about how the reform of judicial appointments should be undertaken.

Given the conclusion that change is needed, the final parts of this paper evaluate the advantages and disadvantages of various options for reform. This analysis illustrates the tension that exists between several of the goals that reform of judicial appointments seeks to achieve. Ultimately, if a supreme law BORA is to be enacted, it is contended that an appointments commission which recommends a shortlist of candidates, from which the Attorney-General selects who to appoint, should be adopted. 


\section{A Supreme Law Bill Of Rights for New Zealand}

\section{A New Zealand Bill of Rights Act 1990}

The New Zealand Bill of Rights Act 1990 is designed to protect the public from the encroachment of fundamental rights by the government. The Act has had a powerful effect on Parliament and the process of law-making by requiring that the AttorneyGeneral report to the House of Representatives on whether a Bill is inconsistent with the Act. ${ }^{1}$ It has also affected statutory interpretation by mandating that judges interpret statutes in a manner consistent with the protected rights. ${ }^{2}$

Despite these substantial effects, the original proposal was for an Act of higher or supreme law status, entrenched to require a special process for amendment. ${ }^{3}$ This would have allowed courts to invalidate legislation which was inconsistent with the Act. It was not enacted at the time because of opposition ${ }^{4}$ but a sense of unfinished business and the possibility that New Zealand will eventually amend the Act to have supreme law status remains. Although this change is not inevitable, it certainly remains possible. Sir Geoffrey Palmer referred to the "constitutional caravan" moving on in suggesting that the time may have come for this reform to occur. ${ }^{5}$

This paper does not address the desirability of this reform, a matter which has been the subject of extensive academic debate. Instead, it assumes that a supreme law BORA is to be adopted and addresses a collateral issue associated with that reform, which has not received academic attention: the implications of a supreme law BORA for New Zealand's system of appointing judges. To assess this issue, it is assumed that the New Zealand Bill of Rights Act 1990 in its present form would be amended to have

1 New Zealand Bill of Rights Act 1990, 7. These reports can be found on the Ministry of Justice website <www.justice.govt.nz>.

2 New Zealand Bill of Rights Act 1990, s 6. For further discussion on this see J F Burrows and R I Carter Statute Law in New Zealand (4th ed, LexisNexis, Wellington, 2009) at 332-383.

3 See A Bill of Rights for New Zealand: A White Paper [1985] AJHR A6.

4 See, for example, New Zealand Law Society "Submissions on the White Paper: A Bill of Rights for New Zealand" (20 December 1985).

5 Geoffrey Palmer "The Bill of Rights After Twenty-One Years: The New Zealand Constitutional Caravan Moves On?" (2013) 11 NZJPIL 260. 
supreme law status, therefore the same rights and freedoms as presently protected would be upheld as higher law. ${ }^{6}$

\section{B What Would Change?}

The fundamental change brought by a supreme law BORA is the ability of courts to strike down laws that are repugnant to the rights contained within it. In determining whether to invalidate legislation, the courts would consider whether the breach of rights was "demonstrably justified in a free and democratic society". ${ }^{7}$ This section assesses the significance of that new power for New Zealand's judges.

From one point of view, this reform would not have a significant impact on the role of judges. This is because judges already possess significantly more power compared to the other branches of government than in the past, notwithstanding the absence of a supreme law BORA. Judges are generally bolder today and more willing to develop the law than they once were. ${ }^{8}$ This is shown, for example, through the development of judicial review of administrative action; ${ }^{9}$ the use of purposive rather than plainmeaning approaches to interpreting legal texts; ${ }^{10}$ and the view that constitutional documents should be interpreted as living organisms that can change to "keep pace with civilisation". ${ }^{11}$

6 There has been significant academic commentary on whether other rights should be protected within the Act, but that is outside the scope of this paper. See, for example, the argument of Butler and Butler on the protection of social and economic rights, property rights and the right to privacy: Andrew Butler and Petra Butler "Protecting Rights" in Caroline Morris, Jonathan Boston and Petra Butler (eds) Reconstituting the Constitution (Springer Verlag, Berlin, 2011) 157.

7 New Zealand Bill of Rights Act 1990, s 4.

8 Geoffrey Palmer "Judicial Selection and Accountability: Can the New Zealand System Survive" in BD Gray and RB McClintock (eds) Courts and Policy: Checking the Balance (Brookers, Wellington, 1995) 11 at 16-17.

9 Paul East "A Judicial Commission" [1995] NZLJ 189 at 189.

10 James Allan "Judicial Appointments in New Zealand: If it were done when 'tis done, then 'twere well it were done openly and directly" in Kate Malleson and Peter H Russell (eds) Appointing Judges in an Age of Judicial Power: Critical Perspectives from around the World (University of Toronto Press, Toronto, 2006) 103 at 109.

11 Ministry of Transport v Noort [1992] 3 NZLR 260 (CA) at 271 per Cooke P. For an earlier example of the Court of Appeal's expansive approach towards the Treaty of Waitangi, see New Zealand Maori Council v Attorney-General [1987] 1 NZLR 641 (CA). 
The second rationale for this view stems from the nature of the protected rights. Sir Kenneth Keith notes that the included rights are generally procedural rather than substantive. This, he suggests, goes some way to avoiding the difficulties associated with unconfined rights, like an equal protection clause, that give judges the ability to second guess the executive and legislature on the end goals of policy and the way those ends are pursued. ${ }^{12}$ Palmer also noted that the civil and political rights presently protected are of "a different and more limited character" than social and economic rights. $^{13}$

Notwithstanding this argument, a supreme law BORA is still likely to have a substantial impact on the role of judges. Enactment of the Charter has had significant implications for Canada's judges. Former Chief Justice of Canada Antonio Lamer said "the Charter has changed our job descriptions" 14 and that the Charter forces judges to make what were formerly political decisions. ${ }^{15}$ Chief Justice Beverly McLachlin expressed similar sentiments, contending that the Charter "turned the tables of power"16 and noting that the Charter forced courts "to grapple with a whole range of hitherto unlitigable issues, many involving social and moral questions of profound importance and difficulty". ${ }^{17}$

Examples of major Charter cases that have arisen in Canada include striking down a reverse onus provision; ${ }^{18}$ striking down a provision criminalising abortion; ${ }^{19}$ and decisions which concerned gay rights ${ }^{20}$ and indigenous rights. ${ }^{21}$ Other cases have dealt with mandatory retirement, Sunday shopping and hate propaganda. ${ }^{22}$ It is foreseeable that cases could emerge on these and similarly prominent and controversial issues in

12 Kenneth Keith "A Bill of Rights for New Zealand: Judicial Review versus Democracy" (1985) 11 NZULR 307 especially at 315-316.

13 Palmer, above n 5, at 268.

14 James Walker "Race," Rights and the Law in the Supreme Court of Canada (Wilfrid Laurier University Press, Waterloo, 1997) at 325.

15 FL Morton "Judicial Recruitment and Selection" in FL Morton (ed) Law, Politics and the Judicial Process in Canada (3rd ed, University of Calgary Press, Calgary, 2002) 117 at 128.

16 Beverly McLachlin "The Charter: A New Role for the Judiciary" (1991) Alta L Rev 540 at 540.

17 McLachlin, above n 16, at 543.

$18 \quad R v$ Morgentaler [1988] 1 SCR 30.

$19 R$ v Oakes [1986] 1 SCR 103.

20 Vriend v Alberta [1998] 1 SCR 493.

$21 R v$ Sparrow [1990] 1 SCR 1075.

22 See McLachlin, above n 16, at 542. 
New Zealand. Therefore, enacting a supreme law BORA is likely to have a considerable impact on the role of judges. It would give them greater power vis-à-vis the legislature and force them to decide cases on issues that were formerly political matters.

Commentators have recognised that the adoption of a supreme law BORA will raise questions about the present system of appointments. A report by Chen Palmer for then Attorney-General Margaret Wilson suggested that, were New Zealand to adopt this reform, "a different approach to the role of the Executive in the appointment and removal of judges might be a necessary consideration as part of wider constitutional reform". ${ }^{23}$ Similarly, Keith suggested that: ${ }^{24}$

The question whether the Bill should be entrenched ... sharpens issues about the use of courts to pursue political purposes ... As the perception of a court's political role is heightened, greater attention focuses on the judicial appointment process and matters of tenure.

The issue is whether the present appointments system will remain fit for purpose once judges have new and significantly wider powers. Will the system enhance public confidence in the independence of the judiciary and judges' suitability to decide BORA cases? Is the process sufficiently transparent and inclusive so as to avoid the perception of a democratic deficit? A prominent part of this issue is the concern that judicial appointments will be politicised. Adopting a supreme law BORA increases the incentive for the government to appoint judges for political reasons, to ensure that the courts will uphold the government's values and not overturn its legislative achievements. Consequently, one of the main issues associated with a supreme law BORA is how to protect judicial independence and prevent the politicisation of judicial appointments, a concept which is examined more closely in the next section.

23 Chen Palmer \& Partners "Memorandum to the Hon Margaret Wilson, Attorney-General: Judicial Administration Issues" (1 November 2002) at [55].

24 Kenneth Keith "Concerning Change: The Adoption and Implementation of the New Zealand Bill of Rights Act 1990" (2000) 31 VUWLR 721 at 743. 


\section{The Politicisation of Judicial Appointments}

Judicial independence is a fundamental element of the rule of law. ${ }^{25}$ It is essential in a liberal democracy that the public are confident their disputes will be resolved according to the law; judges must rule without "fear or favour, affection or ill will". ${ }^{26}$ Judges' salaries may not be reduced during their commission, ${ }^{27}$ and security of tenure, a "cornerstone" of judicial independence, is protected in statute. ${ }^{28}$ These mechanisms protect sitting judges from improper influence by the legislature or executive. However, judicial independence must be protected from the outset - that is, in the way judges are appointed. As the Economist editorialised, "the independence of the judiciary depends on the way judges are selected". ${ }^{29}$

Concern is often expressed that the judiciary and judicial appointments risk becoming politicised if judges can strike down legislation. Yet despite the frequency with which this issue is raised, there is little literature examining what is meant by the concept of "politicised judicial appointments". Some commentators treat the general increase in the power of the courts in relation to the legislature, or the perception that judges are more activist today than in the past, as evidence of politicisation. ${ }^{30}$ However, the focus here is on accusations that judicial appointments - not the role of judges generally may become politicised.

25 Philip A Joseph Constitutional and Administrative Law in New Zealand (4th ed, Brookers, Wellington, 2014) at 797.

26 Oaths and Declarations Act 1957, s18.

27 Constitution Act 1986, s 24.

28 Philip A Joseph "Appointment, discipline and removal of Judges in New Zealand" in HP Lee (ed) Judiciaries in Comparative Perspectives (Cambridge University Press, Cambridge, 2011) 66 at 77. See, for superior court judges, Constitution Act 1986, s 23. For District Court judges, see District Courts Act 1947, s 7. This provision is replicated with some variation in the constituent statutes of the other various inferior courts.

29 Economist (Nov 15 2003), as cited in Peter McCormick "Selecting the Supremes: The Appointment of Judges to the Supreme Court of Canada" (2005) 7 J App Prac \& Process 1 at 28. Also see Martin Friedland "Appointment, discipline and removal of judges in Canada" in HP Lee (ed) Judiciaries in Comparative Perspective (Cambridge University Press, Cambridge, 2011) 46 at 51.

30 See for example Brian Galligan and Peter Russell "The Politicisation of the Judiciary in Australia and Canada" (1995) 67 The Australian Quarterly 85. 
It is clear that judicial appointments cannot be made on the basis of a candidate's political affiliation or membership of a particular political party. Rewarding or punishing a candidate for this reason is unacceptable; Kate Malleson refers to the need to select judges on the basis of merit rather than political patronage. ${ }^{31}$ In New Zealand, this issue is partly sidestepped as it would likely be considered inappropriate for a former Member of Parliament (MP) or prominent member of a political party to be appointed a judge.

Concerns about politicisation go beyond party politics, but it is here that drawing clear lines about what is and is not permissible becomes difficult. Judicial appointments will always possess some element of politics in its broadest sense. Sir Robin Cooke said that appointments by the executive are "inevitably political to a greater or lesser degree". ${ }^{32}$ Gee suggests that: ${ }^{33}$

Decisions such as who to appoint as judges and how to appoint them always have a 'political' dimension, no matter the jurisdiction under discussion. Because appointment processes shape the ability of courts to hold political institutions to account - and, in some jurisdictions, their ability to interpret constitutionally entrenched limits on legislative institutions - it could hardly be otherwise.

Palmer explained the factors he sought when appointing judges as including "forwardlooking people of high intellectual ability, equipped with ample legal learning, experienced, practical, and able to bring essential human qualities to the administration of the law". ${ }^{34} \mathrm{He}$ recognised that some people might consider these factors to be political. ${ }^{35}$ Jack Straw, who was responsible for many judicial appointments in the

31 Kate Malleson "The New Judicial Appointments Commission in England and Wales: New Wine in New Bottles" in Kate Malleson and Peter H Russell (eds) Appointing Judges in an Age of Judicial Power: Critical Perspectives from around the World (University of Toronto Press, Toronto, 2006) 39 at 41.

32 Robin Cooke "Empowerment and Accountability: The Quest for Administrative Justice" (1992) 18 CLB 1326 at 1331 .

33 Graham Gee "The Politics of Judicial Appointments in Canada" in Judicial Appointments: Balancing Independence, Accountability and Legitimacy (Judicial Appointments Commission, 2010) 99 at 99.

34 Geoffrey Palmer Reform (Victoria University Press, Wellington, 2013) at 302.

35 Palmer, above n 34, at 302. 
United Kingdom, expressed a similar view. ${ }^{36}$ Thus some factors which could be broadly considered to be political matters will inevitably factor into judicial appointments. It is impossible, and moreover undesirable, to attempt to remove consideration of these matters from the appointments process.

In contrast, an inappropriately political decision would be an appointment based on a judge's personal views on specific issues that may arise before the courts, or anticipation of how a judge would decide a particular case. Drawing on an example from the United States, the "litmus test" allegedly adopted to check a candidate's position on abortion is an example of an inappropriately political enquiry into how a judge would decide a particular issue.

There is a further need to avoid candidates who are driven by ideology. The decisionmaker's general sense about the extent that the judge will defer to Parliament on social and economic questions is broadly political, but also likely arises in the context of assessing the quality of his or her previous judgments. It is unrealistic to suggest that a factor as general as this could be removed from consideration, especially when vigorous analysis of previous judgments is important when considering judicial elevations.

What must be avoided, however, are appointments based on a demonstrated track record of ideologically driven decisions. This record could be one of an unduly black letter and conservative approach to interpretation, systematic opposition to striking down laws in favour of extreme deference to Parliament, or a record of excessive activism and eagerness to find grounds on which laws can be struck down. A candidate's record may be shown through their judgments or, in the case of new appointments to the bench, their conduct and writing while in practice. ${ }^{37}$

36 See Jack Straw Aspects of Law Reform: An Insider's Perspective (Cambridge University Press, Cambridge, 2013) at 57.

37 For an example of the latter see Dyson Heydon "Judicial Activism and the Death of the Rule of Law" (2003) 47 Quadrant 9, the text of a speech that was later referred to as Heydon's "job application" because he was appointed shortly after its delivery to the High Court of Australia. For further discussion of this see David Williams "The Judicial Appointment Process" [2004] NZ L Rev 39 at 62. 
In summary, a politicised appointment is one that takes into account party politics and a candidate's position on political issues. More broadly, it is a decision which is made in anticipation of how the judge would decide particular cases before them. The system of appointments must guard against the government's ability to stack a court with ideologically driven candidates.

\section{Present System of Judicial Appointments}

At present it is the Attorney-General, a member of the executive, who is responsible for making judicial appointments. This part explains the process by which judicial appointments are made and explores the strengths and weaknesses of this system.

\section{A Greater Standardisation}

Before the 1990s, New Zealand's appointments process was frequently criticised for its lack of transparency. Described as "a highly discreet search process", 38 it was "shrouded in secrecy and mystery". 39 There were no published criteria for judicial office, expressions of interest were not called for, vacancies were not advertised, no interviews of candidates occurred and consultation processes were ad hoc. ${ }^{40}$

Some members of the legal profession supported this highly secretive system. From this perspective, the position's prestige required that the office should seek out the best occupants, rather than would-be occupants seeking judicial office. ${ }^{41}$ Advertising and calling for applications was seen to "diminish the status of the office and thus its attraction as the pinnacle of a legal career". ${ }^{42}$ This claim simply enhances the perception that judicial appointments are insular and based on shoulder-tapping and, thankfully, this view has not prevailed.

Thus the appointments process has improved over time. Greater standardisation occurred following a 1999 review; since then the process has featured criteria for appointment, a clarified consultation process and a system of calling for expressions of

38 John McGrath "Appointing the Judiciary" [1998] NZLJ 314 at 316.

39 Joseph, above n 28, at 66.

40 Joseph, above n 28, at 68 .

41 See McGrath, above n 38, at 316 for a discussion and critique of this perspective.

42 McGrath, above n 38, at 316. 
interest. ${ }^{43}$ The following section explains in more detail how judicial appointments are presently made.

\section{B Judicial Appointments Today}

Very few statutory provisions regulate judicial appointments. The Judicature Act 1908 provides that "Judges of the High Court shall be appointed by the Governor-General in the name and on behalf of her Majesty". ${ }^{44}$ Judges must have held a practising certificate as a barrister or solicitor for at least seven years, ${ }^{45}$ although most have had at least 15-20 years of legal experience before their appointment. ${ }^{46}$ Shortlisted candidates must undertake not to resume legal practice upon retiring as a judge. ${ }^{47}$

While it is the Governor-General who appoints judges, it is done on the advice of the Attorney-General. Although the process adopted by a particular Attorney-General is prescribed neither by statute nor by regulation, successive Attorneys have adopted a broadly similar process. ${ }^{48}$ In 2013 Attorney-General Christopher Finlayson published a protocol setting out procedures and criteria for High Court appointments. ${ }^{49}$ Details of this process are described below.

Prospective candidates may submit an expression of interest form, which are called for by public advertisement, or they may be nominated during the consultation process and invited to apply. Candidates must provide a curriculum vitae and a declaration on issues like their health and financial position. ${ }^{50}$ The Judicial Appointments Unit, part

43 Patrick McCabe "Appointing Judges" [2004] NZ L Rev 244 at 244.

44 Judicature Act 1908, s 4(2).

45 Judicature Act 1908, s 6. Also see District Courts Act 1947, s 5(3).

46 Ministry of Justice Appointing Judges: A Judicial Appointments Commission for New Zealand? (Government Printer, Wellington, 2004) at 13.

47 Joseph, above n 28, at 69.

48 Allan, above n 10, at 105.

49 See Ministry of Justice High Court judges appointment protocol (26 April 2013). Other former Attorneys-General and Solicitors-General have summarised the processes adopted while they were in office. See, from former Attorneys-General: Palmer, above n 8, at 41-52; East, above n 9, at 189-190; and Margaret Wilson "Appointing Judges the New Zealand Way" (2014) 21 Waikato Law Review 41 at 46-47. See, from former Solicitors-General: McGrath, above n 38, at 314-315; and Terrence Arnold "Judicial Appointments" (Speech to the New Zealand Bar Association Conference, Wellington, August 2003) at 2-3.

50 Ministry of Justice, above n 49, at Appendix 2. 
of the Ministry of Justice, provides administrative assistance throughout the process and holds a confidential database containing the names of those who have expressed interest and are qualified for appointment. ${ }^{51}$

The Solicitor-General seeks comment on the candidates from a range of people and organisations. He asks the Chief Justice, the President of the Court of Appeal, and the Chief High Court Judge to give all prospective candidates a rating. ${ }^{52}$ The outcome of this is to create a long-list containing those considered suitable for immediate appointment, those possibly suitable in two to three years, and those in neither category. ${ }^{53}$ This long-list, and the advice received during consultation, is presented to the Attorney-General.

For an upcoming vacancy the Attorney-General, after completing the consultation he or she believes necessary, and with the agreement of the Chief Justice, will determine a shortlist of no more than three names. ${ }^{54}$ Interviews conducted by the Attorney-General or Solicitor-General may occur. The Attorney-General will select one candidate from the shortlist, mention the appointment in Cabinet, and formally advise the GovernorGeneral to make the appointment. ${ }^{55}$ The shortlisting process is repeated for each upcoming High Court vacancy or appointment.

District Court appointments follow a similar process. The most significant difference from the High Court appointments system is that a panel conducts interviews of shortlisted candidates. ${ }^{56}$ This panel consults with the Solicitor-General and the President of the Law Society before making its recommendation to the AttorneyGeneral. ${ }^{57}$ Court of Appeal and Supreme Court appointments typically occur through judicial promotion. Again there is little direction from legislation. Although

51 Joseph, above n 28, at 68 .

52 Ministry of Justice, above n 49.

53 The Solicitor-General confers annually with the Chief Justice, the President of the Court of Appeal, the Chief High Court Judge, and the presidents of the Law Society and Bar Association, to ensure the long-list remains current.

54 Ministry of Justice, above n 49, at Appendix 2.

55 See ss 4(2) and 57(2) of the Judicature Act 1908 and s 17 of the Supreme Court Act 2003.

56 Arnold, above n 49, at 3. The panel comprises the Chief District Court Judge, the relevant Head of Bench (for appointments to the Family, Youth, Environment or Employment Court), the Executive Judge for the region and a representative of the Ministry of Justice.

57 Joseph, above n 28, at 70. 
appointment directly from the profession is permitted for both courts, ${ }^{58}$ this rarely occurs for Court of Appeal appointments and has never occurred for the Supreme Court. $^{59}$

There are two main exceptions to the process outlined above. The Minister of Māori Affairs recommends the appointment of judges to the Māori Land Court. ${ }^{60}$ The Prime Minister recommends the appointment of the Chief Justice, as the Chief Justice is head of the judiciary ${ }^{61}$ and Administrator of the Government when the Governor-General is overseas or unable to perform the office. ${ }^{62}$ The Law Commission recently expressed approval of this exception, ${ }^{63}$ and the Prime Minister's role is to be codified. ${ }^{64}$

\section{Advantages and Disadvantages}

This section outlines the advantages of the system and points out its main weaknesses. The primary disadvantages of the present system are the lack of transparency and the few formal checks and balances that limit the Attorney-General's exercise of discretion. Particular attention is therefore paid to how the system safeguards the political neutrality of appointments.

A key feature of the present appointments process is the widespread consultation that occurs. $^{65}$ This consultation seeks to gather a diverse group of candidates and

Judicature Act 1908, s 57; and Supreme Court Act 2003, s 20.

Joseph, above n 28, at 69.

See Te Ture Whenua Māori Act (Māori Land Act) 1993, s 7(2A), which requires that Māori land court judges have knowledge of te reo Māori, tikanga Māori and the Treaty of Waitangi.

Supreme Court Act 2003, s 18(1).

Letters Patent Constituting the Office of Governor-General of New Zealand 2006, cl 12.

Law Commission Review of the Judicature Act 1908: Towards a New Courts Act (NZLC R126, 2012) at Recommendation 13, also see [5.11].

Judicature Modernisation Bill 2013 (178-2), cl 100.

Those consulted include "the Chief Justice, the President of the Court of Appeal, the Chief High Court Judge, the Secretary for Justice, the president of the Law Commission, the president of the New Zealand Bar Association, the president of the New Zealand Law Society and other organisations or groups representative of lawyers who the Attorney-General believes can contribute names of suitable persons. Such groups may include the Criminal Bar Association, the Māori Law Society, and women lawyers' associations. Nominations are sought from the Minister of Justice, the Minister of Women's Affairs and the Minister of Māori Affairs. Nominations may also be sought from the chair of the justice and electoral select committee and the opposition spokesperson for the 
particularly to find individuals whose career and background are not reflected in the present judiciary. ${ }^{66}$ Further consultation with a smaller group occurs when comment is sought on prospective candidates by the Solicitor-General. ${ }^{67}$ In a recently emerging practice, the opposition shadow Attorney-General is also consulted when the initial long-list is created, a "symbolic endorsement of the apolitical nature of appointments". ${ }^{68}$ However, the protocol produced by Finlayson suggests that the shadow Attorney-General "may" be consulted when nominations are sought, suggesting that this practice is not firmly established. ${ }^{69}$

An important aspect of the consultation process is the high level of judicial involvement. The most recent protocol outlined by Finlayson suggests that the Chief Justice has a veto, because the shortlist of no more than three candidates is created "with the agreement of the Chief Justice". ${ }^{70}$ However, there has been criticism of processes that give judges too much power over appointments, especially if that power amounts to a veto. ${ }^{71}$ A judicial veto is not a firmly established rule; former SolicitorGeneral Sir John McGrath for example said that the judiciary's input does not tightly restrict who may be chosen, and its role is consultative. ${ }^{72}$ This inconsistency highlights one of the drawbacks of the present process; it is not grounded in statute so its operation is ad hoc and lacking in transparency, notwithstanding efforts over the years to standardise the process.

The high level of judicial influence is counterbalanced by the Attorney-General having the final say over appointments. This has two benefits. First, giving the AttorneyGeneral discretion is appropriate because he or she has the democratic mandate as a

Attorney-General portfolio": Ministry of Justice, above n 49. Also see McGrath, above n 38, at 314 and Arnold, above $\mathrm{n} 49$, at 3. See East, above n 9, at 191; and McGrath, above n 38, at 314.

67 Ministry of Justice, above n 49. Here, the Solicitor-General seeks comments from the Chief Justice, the President of the Court of Appeal, the Chief High Court Judge, the New Zealand Law Society, the New Zealand Bar Association, and others as appropriate.

68 Joseph, above n 28, at 68.

69 Ministry of Justice, above n 49.

70 Ministry of Justice, above n 49.

71 See for example, Palmer, above n 8, at 43.

72 McGrath, above n 38, at 316. But see Allan, above n 10, at 105, where it is suggested that senior judges may have an informal veto if they are dead set against someone. 
member of a government that enjoys Parliament's support. ${ }^{73}$ Secondly, giving discretion to the Attorney-General has encouraged the appointment of lawyers with less orthodox backgrounds. ${ }^{74}$

The principal disadvantage of this system is the lack of formal safeguards to limit the Attorney-General's exercise of discretion and, in particular, his or her ability to make politicised appointments. Two main bulwarks protect judicial independence in appointments: first, the conventions that govern the Attorney-General's decisionmaking, and second, the fact that political pressures hold the Attorney-General accountable. The strength of these protections is considered in the next section. The arguments here are not made on the basis of criticism of recent judicial appointments in New Zealand, but rather from the concern that future appointments may be at risk of improper political influence.

\section{$1 \quad$ Strength of the Constitutional Convention}

The first bulwark against political appointments is the convention that the AttorneyGeneral makes appointments based on merit. As Senior Law Officer, the AttorneyGeneral is required by convention to make appointments independently of party political considerations. ${ }^{75}$ The Attorney-General is "guardian of the public interest and exercises an independent function not shared by other ministers". ${ }^{76}$ This is reflected in the convention that appointments are announced, but not discussed or approved, in Cabinet.

McGrath contends that the strength of this convention is often under-estimated and that holders of offices governed by conventional duties have a strong sense of obligation not to fail in those responsibilities. ${ }^{77}$ Arnold expressed similar sentiments, saying "[t]hese conventions are robust, essentially as a result of the scrupulous way in which they have been understood and observed by the relevant actors over many years". ${ }^{78}$ Thus although an Attorney-General could foreseeably breach convention and

73 McGrath, above n 38, at 316.

74 McGrath, above n 38, at 316.

75 Ministry of Justice, above n 46, at [29].

76 Joseph, above n 28, at 67.

77 McGrath, above n 38, at 317. Also see Palmer, above n 8, at 44.

78 Arnold, above n 49, at 7. 
make appointments based on political considerations, McGrath reminds us that "this can be said of many of our offices that are restrained by constitutional conventions". ${ }^{79}$

However, the operation of this convention cannot be equated with the operation of all others. While it is true that all conventions are, by their very nature, at risk of being ignored, not all conventions operate in a like manner or are at equal risk of being breached.

The operation and strength of many conventions can be verified by the public. For example, the public would know if the Governor-General breached convention by refusing to assent to legislation or by acting contrary to a Minister's advice; an appropriate response to the breach could therefore occur. Conversely, while some may question an appointment, only the Attorney-General can know whether the appointment was driven by improper considerations.

Therefore, the convention preventing political appointments is quite unlike other conventions that restrain the exercise of certain public offices. The public must rely on the integrity and assurances of "insiders" to know whether the convention is strong. Unsurprisingly, this provides a lesser sense of certainty about the reliability of the process. McCormick, speaking of the situation in Canada where a very similar appointments process was adopted, summarised the problem: ${ }^{80}$

It may well be that the right people are involved, that they are making their decisions on defensible criteria, and that their advice is strictly followed by the politicians, with purely professional considerations always being preemptive - but since we do not know that this is the case, we have to take it on faith, and this phrase is the very antithesis of transparency.

The fact that several Attorneys-General and Solicitors-General have confirmed that appointments occur independently of political considerations increases confidence in the process. However, doubts are always likely to linger in any system that gives wide discretion to a government minister, especially in a society which is increasingly 
willing to question authority figures and demand greater transparency. ${ }^{81}$ Perceptions of bias will arise, regardless of how impartial appointments are in practice, simply by virtue of the fact that appointments are made by a government minister without public oversight. $^{82}$

\section{Political Accountability}

In addition to the convention against political appointments, a second bulwark exists. As the Attorney-General is a minister, appointments can be subjected to the political accountability that corresponds with that role. This form of protection has two components. First, accountability to Parliament, and therefore the public, affects the conscience of the Attorney-General and "brings home to [him or her] ... the need to make appointments on merit". ${ }^{83}$

The second component is that the Attorney-General may be questioned and held to account for his or her choices, including through Select Committee examination. ${ }^{84}$ Allan drew on the 2004 appointments to the new Supreme Court as evidence of this protection. He contended that, notwithstanding the absence of legal limits, political limits constrained the Attorney-General's exercise of discretion when appointing four members of the new Supreme Court. ${ }^{85} \mathrm{He}$ argued that political pressures led the Attorney-General to elevate the four most senior members of the Court of Appeal. ${ }^{86}$

However, these political limitations are less effective under ordinary circumstances when a single judge is appointed. As the process operates with little transparency, it would be difficult to mobilise political opposition if it was suspected that an appointment was made, or a candidate was rejected, on inappropriate grounds. Former Chief Justice Sir Thomas Eichelbaum reminds us that "[w]hat remain unknown and

81 For further discussion of this change in public attitudes, see for example Thomas Eichelbaum "The Inaugural Neil Williamson Memorial Lecture: Judicial Independence Revisited" (1997) 6 Canterbury L Rev 421 at 421.

82 See Jeffrey Jowell "The Growing International Consensus in Favour of Independent Judicial Appointment Commissions" in Judicial Appointments: Balancing Independence, Accountability and Legitimacy (Judicial Appointments Commission, 2010) 1 at 3.

83 McGrath, above n 38, at 316

84 Palmer, above n 8, at 42.

85 Allan, above n 10, at 106-107.

86 Allan, above n 10, at 107. 
unseen are the cases where for politically influenced reasons, particular persons are not appointed". ${ }^{87}$ Thus the protection afforded by political accountability is fairly weak given that appointments occur in the absence of open and transparent procedures.

Another element to the Supreme Court appointments episode calls these safeguards into question. Then Attorney-General Margaret Wilson, while discussing the appointments to the new Supreme Court and whether they were to be solely based on seniority, has said: ${ }^{88}$

This was the only time I can say there was any discussion in Cabinet of judicial appointments. I had suggested an appointment panel but this did not gain support. Unfortunately one of my ministerial colleagues suggested subsequently that the appointments were not made on merit, which created a brief furore and convinced me that the practice of not discussing judicial appointments in Cabinet was a good policy.

It is unclear whether Cabinet discussed the method of judicial appointments generally or whether discussion of the actual candidates for appointment occurred. The latter possibility is a worrying breach of convention. Although this was an unusual situation as the government was under political pressure regarding judicial appointments, similar pressures could foreseeably arise again. The fact that an important convention governing appointments is perhaps weaker than is generally claimed is a cause for concern. Eichelbaum has said that it is not easy for modern Attorneys-General, when fulfilling their traditionally independent role in relation to the judiciary, to distance themselves from their Cabinet colleagues and collective Cabinet responsibility. ${ }^{89}$

The primary disadvantages of the present system of appointments are its lack of transparency and the fact that the Attorney-General exercises a wide degree of discretion, with little beyond his or her integrity to safeguard the non-political nature of appointments. The next part examines Canada's experience after its Charter was adopted, to help assess whether New Zealand's present appointments system should be retained if a supreme law BORA was enacted.

87 Eichelbaum, above n 81, at 427.

88 Wilson, above n 49, at 47-48.

89 Eichelbaum, above n 81, at 427. 


\section{Is The Present System Suitable? Canada's Experience}

This part uses Canada as a case study in how enacting a supreme law instrument affects judicial independence and judicial appointments. Canada did not address the collateral issue of judicial appointments when its Charter was enacted. Post-Charter, appointments came under far greater scrutiny and the existing appointments system was widely criticised, but lasting and substantial reform has not been forthcoming.

\section{A Why Canada?}

Because of its similarities with New Zealand and the fact that it moved from an instrument similar to the New Zealand Bill of Rights Act 1990 to the Charter, Canada is a useful case study. Like New Zealand, Canada was a colony that imported the common law and legal traditions of Britain. Appeals to the Judicial Committee of the Privy Council ended in 1949. ${ }^{90}$ A significant difference between New Zealand and Canada is Canada's system of provinces and territories. The federal model affects judicial appointments; there are both federal and provincial courts, with a hierarchy within each category and varied systems of appointment. This paper focuses on appointments to the Supreme Court of Canada (SCC), because these appointments came under increased scrutiny after the Charter's adoption and were significantly reformed as a result.

The precursor to the Charter was the 1960 Canadian Bill of Rights, an ordinary federal statute with the same status as the New Zealand Bill of Rights Act 1990. It was perceived as ineffective because of the courts' hesitance to use the law forcefully, ${ }^{91}$ so in 1982 the Charter, a comprehensive bill of rights with supreme law status, was enacted.

Although the courts may strike down laws that are inconsistent with the protected rights, the Charter makes several concessions to parliamentary sovereignty. Like s 5 of the New Zealand Bill of Rights Act 1990, s 1 of the Charter provides that the rights

90 See McCormick, above n 29, at 8-9 for further background on this reform.

91 Munroe Eagles and Sharon A Manna "Politics and Government" in Patrick James and Mark Kasoff (eds) Canadian Studies in the New Millennium (University of Toronto Press, Toronto, 2008) 65 at 91. Also see Ian Greene The Charter of Rights (Lorimer, Toronto, 1989) at 23-29. Notably the Supreme Court did find one law "inoperable" due to breach of the Bill of Rights: see $R v$ Drybones [1970] SCR 282. 
and freedoms are "subject only to such reasonable limits prescribed by law as can be demonstrably justified in a free and democratic society". The "Notwithstanding Clause" allows provincial and federal legislatures to approve the application of a law notwithstanding a judicial finding that it breaches the Charter, ${ }^{92}$ but is rarely used. ${ }^{93}$

At the time the Charter was enacted, SCC appointments occurred in a manner very similar to New Zealand's present system. Appointments were made by the GovernorGeneral who, in accordance with convention, was advised by the Prime Minister for appointment of the Chief Justice and by the Minister of Justice, likely with the Prime Minister's input, for other SCC appointments. ${ }^{94}$ As in New Zealand, this process was characterised by widespread consultation with members of the bench and bar. ${ }^{95}$ Although appointments before 1970 were frequently based on political connections, ${ }^{96}$ a major change in focus meant that appointments since that time were driven largely by competence rather than patronage. ${ }^{97}$ However, research reveals no reference to constitutional conventions governing the non-political nature of appointments, thus the protection of this value appears weaker than in New Zealand.

\section{B Public Perception of Judicial Appointments}

This section outlines the public's response to the judiciary's ability to make policyladen decisions, in particular highlighting several worrying cases where civil society groups attempted to lobby decision-makers on appointments. This illustrates the

92 Canadian Charter of Rights and Freedoms, Part I of the Constitution Act 1982, being Schedule B to the Canada Act 1982 (UK) c 11, s 33.

93 Janet Hiebert "New Constitutional Ideas: Can Parliamentary Models Resist Judicial Dominance When Interpreting Rights?" (2004) 82 Tex L Rev 1963 at 1967-1968. Also see James Allan Democracy in Decline: Steps in the Wrong Direction (McGill-Queen's University Press, Montreal, 2014) at 28-29.

94 Peter Hogg "Appointment of Justice Marshall Rothstein to the Supreme Court of Canada" (2006) 44 Osgoode Hall LJ 527 at 528.

95 Lori Hausegger, Matthew Hennigar and Troy Riddell Canadian Courts (Oxford University Press, Oxford, 2009) at 166. Advice is sought from the Chief Justice of the SCC, the Attorney-General from the relevant region, senior members of the law societies and bar associations of that region, and senior judges from the courts in the area.

96 See McCormick, above n 29, at 14; and R Blake Brown "The Supreme Court of Canada and Judicial Legitimacy: The Rise and Fall of Chief Justice Lyman Poore Duff" (2002) 47 McGill LJ 559 at 566.

97 Hausegger, Hennigar and Riddell, above n 95, at 167. 
additional pressure and scrutiny placed on the judicial appointments system in the post-Charter environment.

\section{$1 \quad$ Public Opinion}

Public perceptions of the judiciary and judicial appointments have been affected by the Charter. A 2002 poll indicated that two thirds of the public supported popular election of SCC judges. ${ }^{98}$ Although there is no equivalent polling from before the Charter's adoption, this number is surprisingly high and likely reflects Canadians' increased awareness of judges' policy-making function. ${ }^{99}$ Another 2003 poll found that Canadians were concerned by the increased powers of judges, finding that 71 per cent of Canadians agreed that "it should be up to Parliament and provincial legislatures, not the courts, to make laws in Canada". ${ }^{100}$

\section{$2 \quad$ Lobbying}

Recognising the increased power of judges, many civil society groups have responded by seeking to influence judicial appointments. The National Action Committee on the Status of Women began in 1981 to lobby for the appointment of a woman "acceptable to [their] purposes" on the SCC. ${ }^{101}$ Their later "influencing the influencers" campaign aimed to influence judicial appointments and judges' ongoing professional education. ${ }^{102}$ A prominent judgment concerning abortion prompted a member of Choose Life Canada to say that her group would attempt to influence future appointments. ${ }^{103}$ The President of an opposing organisation responded that, while her

98 Florian Sauvageau, David Schneiderman and David Taras The Last Word: Media Coverage of the Supreme Court of Canada (UBC Press, Vancouver, 2006) at 28.

99 FL Morton "Judicial Appointments in Post-Charter Canada: A System in Transition" in Kate Malleson and Peter H Russell (eds) Appointing Judges in an Age of Judicial Power: Critical Perspectives from around the World (University of Toronto Press, Toronto, 2006) 56 at 56.

100 Morton, above n 99, at 56.

101 Justice Committee "NAC Memo" (September 1981) at 5; Justice Committee "NAC Memo" (March 1981) at 4, as cited in Morton, above n 99, at 60.

102 Morton, above n 99, at 61.

103 "Public to demand say in Court Appointments" Lawyers Weekly (12 February 1988) at 1, as cited in Morton, above n 99, at 61. 
group had never tried to influence appointments previously, it would if necessary in the future. ${ }^{104}$

The obvious follow-up question is whether this lobbying has actually worked; have interest groups had inappropriate influence, or are these statements empty words?

The first response is that there is some evidence that lobbying efforts have been successful, but there are other instances of unsuccessful lobbying. An example of the latter was a feminist organisation's failed efforts to have Mary Eberts appointed to the SCC, despite a campaign that included phone calls, letters and personal representations to the Prime Minister's Office and Cabinet ministers. ${ }^{105}$ In contrast, the lobbying effort of ÉGALE, a prominent gay rights advocacy group, appears to have been successful. In 1997 the group lobbied members of the Government about a SCC appointment; remarkably, members of ÉGALE were even given the Government's shortlist of candidates. ${ }^{106}$ The judge appointed, Michèle Bastarache, joined the majority shortly after his appointment in Vriend $v$ Alberta, a major victory for gay rights groups. ${ }^{107}$

The second and better response to this question is that whether or not lobbying is successful is not the problem. Instead, the perception that lobbying has occurred and might influence appointments is concerning. In the previous example, Bastarache's appointment may have been wholly non-political and he may be well qualified for the role, yet the secretive nature of appointments means the public cannot be certain and must take that on faith. Consequently, questions continue to linger about the place of politics in the decision, which has a de-legitimising effect regardless of whether the decision was in fact based on political factors.

Lobbying was not restricted to civil society groups; Canadian MPs have similarly stated the importance of influencing appointments. MP James Jepson said that "[w]e now have a chance to put men and women on the bench with a more conservative

104 "Public to demand say in Court Appointments" Lawyers Weekly (12 February 1988) at 1, as cited in Morton, above n 99, at 61.

105 Jeffrey Simpson Faultines: Struggling for a Canadian Vision (Harper Collins, Toronto, 1993) at 102.

106 FL Morton "Reforming the Judicial Appointment Process for the Supreme Court of Canada" Presentation to Standing Committee on Justice and Human Rights (1 April 2004).

107 Vriend v Alberta [1998] 1 SCR 493. 
point of view". ${ }^{108}$ Although at the time his comments represented a "sharp break" from Canadian practice, in retrospect "they marked the beginning of a growing demand for greater transparency and public participation in Supreme Court appointments". 109

\section{Reform of Judicial Appointments}

The SCC appointment system has undergone significant reform over the past decade. Although questions have been raised about the political neutrality of some appointments, as discussed above, concern about existing examples of patronage was not the main trigger for reform; instead it was the judiciary's increased power compared to the legislature and concern about the lack of transparency that drove reform. ${ }^{110}$ Criticising a "democratic deficit" in Canada due partly to the system of appointing judges, Prime Minister Paul Martin charged the House of Commons Justice Committee with suggesting more transparent alternatives. ${ }^{111}$ Its recommendations were the creation of an appointments commission and legislative scrutiny of prospective appointees. ${ }^{112}$ Attempts to implement these recommendations are assessed below.

\section{Early Reforms}

In 2004 the Minister of Justice announced that two SCC nominees would be subject to a parliamentary review. Despite lofty goals, the reality was disappointing. The review occurred in a single session held one day after the announcement, very few MPs were involved, and the panel had no power to delay or veto the nomination. ${ }^{113}$ The panel questioned neither the candidates themselves nor the Prime Minister who selected them; instead, questions were directed only at the Minister of Justice, who stated explicitly that it had not been his decision. ${ }^{114}$ One journalist likened this as akin to "sending your mother to do your job interview". ${ }^{115}$

108 Morton, above n 99, at 61.

109 Morton, above n 99, at 61.

110 See Gee, above n 33, at 109.

111 McCormick, above n 29, at 2.

112 Hausegger, Hennigar and Riddell, above n 95, at 169.

113 McCormick, above n 29, at 29.

114 McCormick, above n 29, at 29.

115 Hausegger, Hennigar and Riddell, above n 95, at 169. 
Given the derision that greeted the previous attempt to add greater transparency to the process, a new approach involving an advisory committee was announced in $2005 .^{116}$ What at first appeared to be a significant reform lacked substance. The committee was dominated by politicians and federal appointees ${ }^{117}$ and had a very narrow role. After starting with a list of eight candidates provided by the Department of Justice, its role would be cutting the list to three. In-person interviews of candidates would be banned, and the committee could not add additional names to the initial eight. A decision would ultimately be made by the Prime Minister, who could make an appointment from outside the shortlist if he or she considered it necessary. After an appointment, the Minister of Justice would appear before the Justice Committee to explain the appointment process.

After this commission created its shortlist, the governing party lost an election. One of the policies of the newly elected Conservative Government was a public, parliamentary interview process for proposed SCC appointees. ${ }^{118}$ Thus the new Government chose one name from the shortlist created by the former Government's advisory committee. Rather than the Minster of Justice appearing before the Justice Committee, the new Government had the nominee, Marshall Rothstein, appear.

\section{Legislative Hearings}

Over a three hour televised session Rothstein was questioned by 12 MPs, representing the various political parties. A constitutional expert moderated the session and outlined the types of questions that were not appropriate, for example, the nominee's position on hypothetical cases or why he decided a particular case the way he did. ${ }^{119}$ While some MPs raised controversial topics like abortion and same-sex marriage, the Chair told the nominee that he did not have to respond. ${ }^{120}$ The MPs were "extremely polite and deferential", some apologetic that he was even subjected to the review, and far less

116 Ministry of Justice Proposal to Reform the Supreme Court of Canada Appointments Process (April 2005). This proposal is explained and critiqued by McCormick, above n 29, at 39-41.

117 The committee was comprised of one member nominated by each political party recognised in the House of Commons, one retired judge, one member nominated by the Attorney-General of the relevant province for which the appointment is made, one member nominated by the law society of the relevant province, and two lay members nominated by the Minister of Justice.

118 Hogg, above n 94, at 529.

119 Hogg, above n 94, at 538.

120 Hausegger, Hennigar and Riddell, above n 95, at 142. 
aggressive in their questioning than their American counterparts. ${ }^{121}$ Committee members had no voting power but were invited to submit their views to the Prime Minister, who later formally announced Rothstein's appointment. ${ }^{122}$

This new process was controversial. Chief Justice Beverly McLachlin opposed the hearing, as did various former presidents of the Canadian Bar Association and other prominent legal professionals. ${ }^{123}$

A different process was adopted in 2008. A committee of five MPs - two from the government caucus and one from each opposition party - would privately review a list of names put forward by the government and produce a three person shortlist. ${ }^{124}$ However, the committee descended into partisan bickering, so the Prime Minister simply announced the nomination of Thomas Cromwell following discussions with the Leader of the Opposition. ${ }^{125}$ Although it was intended that the nominee would appear before a parliamentary committee, an election intervened and Cromwell was appointed without a hearing. ${ }^{126}$ Thus the appointment was essentially a reversion to the previous process.

After this fiasco, some consistency was achieved. ${ }^{127}$ Several subsequent appointments were made where a committee of MPs reviewed a list of candidates to form a shortlist, from which the Prime Minister and Minister of Justice selected who to appoint. The composition of these committees was odd: only MPs were involved and in each case a majority of members were from the governing party. A legislative hearing with the chosen candidate then took place.

After several years of consistency, appointments returned to a state of flux in 2013, following the appointment of Marc Nadon. After being sworn in as a SCC Judge,

121 Hausegger, Hennigar and Riddell, above n 95, at 142.

122 Hogg, above n 94, at 530.

123 Jacob Ziegel "A New Era in the Selection of Supreme Court Judges" (2006) 44 Osgoode Hall Law Journal 547 at 548 .

124 Department of Justice of Canada "Minister of Justice Announces Selection Process for the Supreme Court of Canada" (press release, 28 May 2008).

125 Adam Dodek "Reforming the Supreme Court Appointment Process, 2004-2014: A Ten Year Democratic Audit" (University of Ottawa, Ottawa, 2013) at 15.

126 Dodek, above n 125, at 15.

127 See Dodek, above n 125, at 14-17. 
Nadon's appointment was nullified by the Supreme Court; he was deemed ineligible based on legislation which requires that three SCC Judges be from Quebec. ${ }^{128}$ Further problems arose because the shortlist created by the committee of MPs was subsequently leaked to the media. ${ }^{129}$ The appointment of the most recent Justice, Clément Gascon, was simply announced by the Prime Minister. This reversion to the original appointments process occurred because the Government "no longer trusted" the reformed appointments system. ${ }^{130}$ It is unclear what process will be adopted in future. ${ }^{131}$

\section{$V \quad$ Reforming Appointments in New Zealand}

Canada's experience - enacting the Charter while initially retaining a judicial appointments system similar to New Zealand's - offers several main conclusions. It suggests that reform of New Zealand's appointments system is necessary and indicates how that reform should proceed.

\section{A Reform is Needed}

Canada's experience shows that enacting a supreme law BORA is likely to expose New Zealand's judicial appointments system to far greater scrutiny, and it seems unlikely to be able to withstand the additional pressure inevitably placed upon it. Canada enacted a supreme law instrument but did not concurrently address the collateral consequences of this reform; it "never really worked through the implications of wedding ... an American-style interventionist court with a traditionally English style of appointing judges". ${ }^{132}$

128 In the Matter of a Reference by the Governor in Council concerning sections 5 and 6 of the Supreme Court Act, R.S.C. 1985, c. S-26, as set out in Order in Council P.C. 2013-1105 dated October 22, 2013 [2014] 1 SCR 433.

129 See Sean Fine "The secret short list that provoked the rift between Chief Justice and PMO" Globe and Mail (online ed, May 23 2013).

130 Sean Fine "Legal observers worry future judicial appointments will be done in secret" Globe and Mail (online ed, 18 September 2014). Also see Kim Mackrael and Sean Fine "Tories changed tack on Supreme Court appointments after Globe report" Globe and Mail (online ed, 16 September 2014).

131 Fine, above n 130.

132 McCormick, above n 29, at 17, referring to Morton, above n 99. 
The principal disadvantage of the previous Canadian approach was the wide discretion exercised through a secretive process by members of the government, with little beyond their integrity to safeguard the non-political nature of appointments. The ease with which the system could be criticised meant that, following high-profile Charter cases, the media and politicians increasingly questioned how appointments were made. ${ }^{133}$ Judicial appointments also became a prominent political issue; for example, parties campaigned on policies regarding judicial appointments, ${ }^{134}$ and a sub-theme of the 2004 federal general election campaign was a concern about the kind of judicial appointments that a new conservative Prime Minister might make. ${ }^{135}$

The system's fragility was exposed. Thus over time, almost every major Canadian newspaper noted the growing political influence of Canada's judges and criticised the nature of their appointment. ${ }^{136}$ This led to increased agreement that improvements were needed, hence the attempts at reform.

Canada's experience suggests that if New Zealand enacts a supreme law BORA, the judicial appointments system will similarly be subject to significantly more scrutiny. It has not been immune to criticism notwithstanding the absence of a supreme law BORA; a former Chief Justice, former President of the Court of Appeal and former Attorney-General have, among others, all called for reform. ${ }^{137}$ As occurred in Canada, these calls are only likely to grow louder once judges have the power to strike down legislation.

New Zealand's present appointments process shares the same fundamental weaknesses as the previous Canadian system. The non-political nature of appointments is predominantly safeguarded by the integrity of a member of the executive rather than

133 See for example Sauvageau, Schneiderman and Taras, above n 98, at 159-160, which considers the widespread coverage of the Supreme Court's decision in $R v$ Marshall, including criticism of judicial appointments and calls for a more transparent system. Also see Jacob Ziegel "Merit, Selection and Democratization of Appointments to the Supreme Court of Canada" in FL Morton (ed) Law, politics and the judicial process in Canada (3rd ed, University of Calgary Press, Calgary AB, 2002) 159.

134 For example, the Conservative party campaigned on a policy of public, parliamentary interviews for proposed SCC appointees.

135 McCormick, above n 29, at 27.

136 Hausegger, Hennigar and Riddell, above n 95, at 141.

137 See Eichelbaum, above n 81; Cooke, above n 32; and Wilson, above n 49. 
by formal checks and balances. Too much power is concentrated in the hands of one individual, especially since the power to shape the courts' composition would be more potent than ever if judges were capable of striking down legislation. The appointments process lacks transparency and is closed and exclusive; it "makes no effort to elicit the support for appointments of members of the legislature whose laws the appointee will eventually review". ${ }^{138}$ Thus the present system of appointments is insufficiently robust to withstand the scrutiny that will inevitably be placed upon it should a supreme law BORA be enacted. Reform of the judicial appointments process should occur.

\section{B Character of the Necessary Reform}

New Zealand should learn from Canada's experience, which is largely an example of what not to do when reforming judicial appointments. Four conclusions can be drawn from the Canadian case study: reform must be proactive, codified, bipartisan and responsive.

\section{$1 \quad$ Proactive}

First, reform of judicial appointments must be proactive. New Zealand should consider changing how judges are appointed prior to, or alongside, a decision to enact a supreme law BORA.

There is a contrary argument that a supreme law BORA should be enacted without addressing collateral issues like judicial appointments. On this view, it is unnecessary to pre-empt the effects of such reform and prematurely respond to problems that may not eventuate. Issues can be addressed at a later date if and when they do arise. This argument - the "if it ain't broke, don't fix it" approach to law reform - intuitively makes a lot of sense.

However, Canada's experience shows why this approach is problematic. Despite recognition of the need for improvement, in Canada there was little agreement on the appropriate reform. Although adjustments have been made since 2004, these have varied widely; some appointments have involved a screening or appointments commission (of differing compositions - most recently made solely of MPs, the

138 Jowell, above n 82, at 3. 
majority of which were from the governing party), others have included legislative hearings, and others have been made by reverting to the previous system. ${ }^{139}$

Why has achieving lasting change been so difficult in Canada? Commentators see the government's vested interest in retaining control over appointments as a major inhibitor to substantive reform. The government's main concern, it is suggested, is with superficial appearances rather than genuine improvement. ${ }^{140}$

Failing to address wider issues like judicial appointments before enacting a supreme law BORA risks creating a political context in which achieving genuine reform becomes increasingly difficult. To avoid this, proactive reform which addresses collateral issues like judicial appointments alongside the decision to adopt a supreme law BORA is desirable. A similar argument is often advanced in favour of enacting a supreme law BORA itself; even in the absence of rights infringements in the past "[i]t is much better not to wait for a flood before we build the dam. The planning and building should take account of the threat by careful thought and execution in advance". ${ }^{141}$

Furthermore, Paul East suggested that a judicial appointments commission, once created, would be politically impossible to disband. ${ }^{142}$ This scenario illustrates the desirability of a measured approach to reform over a knee-jerk response to pressures placed on the system.

\section{Codified}

The second conclusion is that reform must be codified. The changes in Canada were not; instead the process to be adopted was simply announced by the Minister of Justice when a vacancy arose. ${ }^{143}$ The series of fluctuating and inconsistent methods of appointment adopted in Canada undermine the aims of increasing transparency and public confidence in appointments. Codifying reform would ensure greater consistency in the way judges are appointed.

139 Dodek, above n 125, at 14-17.

140 McCormick, above n 29, at 42.

141 A Bill of Rights for New Zealand: A White Paper [1985] AJHR A6 at [4.24].

142 East, above n 9, at 190.

143 See, for example, Department of Justice of Canada "Minister of Justice Announces Selection Process for the Supreme Court of Canada" (press release, 28 May 2008). 


\section{Bipartisan}

Thirdly, any reform must be bipartisan. That was not the case in Canada; as outlined above, the varying systems of appointment have taken place under two governments and the method of appointing judges became a political issue. Appointments are currently in a state of flux and it is not clear that a new government would retain the system implemented by the present government. This is a worrying state of affairs for an issue of constitutional importance. A bipartisan approach to reform would go some way towards insulating appointments from political attacks and ensuring consistency in the method of appointment.

\section{$4 \quad$ Responsive}

The fourth conclusion is that reform of appointments must actually respond to the problem. Canada failed to precisely define the present problem and respond substantively to it. Consequently, the value of its reforms is limited.

The legislative hearing process did little to limit the Prime Minister's exercise of discretion. While the Prime Minister contended that the hearing process "brought unprecedented openness and accountability to the process", ${ }^{144}$ this is undoubtedly an overstatement considering that many questions were off limits and the hearings did not offer reasons why one candidate was chosen over another qualified individual. Furthermore, many of the questions asked at the various hearings were inane and gave MPs little information of value in determining whether the appointee was qualified. ${ }^{145}$ The MPs had no voting power and the nomination could have proceeded even if they had expressed disapproval of the nominee. Therefore the reform appears to be little more than rubber stamping of nominees; it creates a public process but does not truly create a check on the Prime Minister's exercise of discretion.

The more recent involvement of a committee of Canadian MPs is also of questionable value. The composition of these committees was odd; in each case the governing party's MPs constituted a majority on the committee and non-political actors like

144 Prime Minister's Office "Prime Minister announces appointment of Mr. Justice Marshall Rothstein to the Supreme Court" (press release, 1 March 2006).

145 Transcripts from the more recent hearings are available on the Ministry of Justice website, <http://canada.justice.gc.ca〉. Also see Peter Hogg "Appointment of Thomas A Cromwell to the Supreme Court of Canada" (2009) 47 SCLR 413 at 426. 
judges or law society representatives were excluded. The dominance of government MPs, and the absence of independent non-political actors, means that the committee cannot be considered an impartial body independent of government. Members of the Government could simply tell the members of their caucus on the committee to ensure that certain candidates make the shortlist.

Thus the problem with this reform is that it does not act as an effective and independent check on the Prime Minister's exercise of discretion. The value of the legislative hearing was instead to allow MPs and the public to get to know the appointee and to hear their views on, for example, their role as judges or their understanding of Charter rights. The hearing, Hogg contended, sent a reassuring message about the nominee's abilities and integrity. ${ }^{146} \mathrm{He}$ also saw the hearing as a useful antidote to charges of judicial activism that frequently arise following unpopular decisions. $^{147}$

While these are undoubtedly positive consequences, they do not address one of the main problems with the present system: the lack of checks on the executive's responsibility for judicial appointments. There was a failure to define the precise nature of the problem and respond accordingly, meaning the reforms enacted in Canada are more superficial than substantive. Therefore the next section defines the present problem and determines what reform of appointments is really trying to achieve, creating a framework within which possible reforms can be assessed.

\section{The Purpose of Reform}

To enact responsive and lasting reform, it is necessary to identify precisely what the reform aims to achieve. McGrath summarised the values to be applied in the appointment process as political neutrality, adherence to merit based criteria, maintaining public confidence in the judiciary and accountability for appointments. ${ }^{148}$

The first value identified - political neutrality - is of central importance in a system with a supreme law BORA. There are twin goals. The first is to enhance the political neutrality of appointments and prevent the government from being able to stack a court

146 Hogg, above n 94, at 534.

147 Hogg, above n 94, at 534.

148 McGrath, above n 38, at 317. 
with ideologically driven candidates. The second aspect is to quell the perception that ideological appointments could occur. Even if appointments are politically neutral in fact, unless they are perceived to be so the door is open to political sensations and attacks in response to appointments or following unpopular judgments. As discussed above, part of a Canadian federal election campaign concerned the sorts of conservative judicial appointments that a new government might make. ${ }^{149}$ As these sorts of attacks have a corrosive effect on public confidence in the judiciary's independence, the appointments system should aim to reduce the risk that they would occur.

However, political neutrality is not the only goal; reform should not aim solely to enhance neutrality at the expense of other values. McGrath emphasises adherence to merit based criteria. Undoubtedly, appointments must be based on merit, not irrelevant political considerations, but merit cannot mean legal ability alone. The appointments system should also foster the appointment of individuals with empathy and encourage greater diversity among appointees. These characteristics, while important in any group of judges, are of heightened importance when judges have the ability to strike down laws and make what are in effect political decisions. Jeffrey Jowell suggests that "qualities such as social sensitivity or political sagacity" are needed if a supreme law BORA is enacted. ${ }^{150}$

To Beverly McLachlin, former Chief Justice of Canada, it is particularly important that judges possess the following qualities in the post-Charter environment: ${ }^{151}$

...they must remain in touch with the world about them if they are to render relevant and helpful decisions. It is also obvious that the composition of the courts should reflect insofar as possible the broad mosaic of our society, the better to guard against the predominance of uniform insularity.

McGrath also notes that public confidence in the judiciary must be protected. In addition to maintaining confidence in the judiciary's independence, the appointments system should foster the democratic legitimacy of judges. While necessary in any system, democratic legitimacy is of heightened importance once a supreme law BORA

149 McCormick, above n 29, at 27.

150 Jowell, above n 82, at 3.

151 McLachlan, above n 16, at 543. 
is enacted because the reduction of Parliament's power compared to the courts may be seen as undemocratic. Canada has grappled with a perceived democratic deficit following the enactment of the Charter, partly because of its system of appointing judges. ${ }^{152}$

Accountability for appointments is the fourth value identified by McGrath and is linked to the point on public confidence. If judicial appointments are made without sufficient input from MPs and the government, weakening the sense of accountability to the public, the judiciary risks being perceived as elitist and unqualified to assess the political aspects that inform a decision to strike down legislation.

Other important criteria include that the process should protect confidentiality, to avoid the risk that good candidates will be deterred from seeking judicial office. Unnecessary expense or administrative burdens should be avoided. The system of appointments must also accord with New Zealand's common law tradition and political culture.

Thus a key goal of reform is to create a system where judicial appointments are perceived to be, and are in fact, free from the sorts of improperly political considerations that were identified above. However, this goal cannot be the sole focus at the expense of the other values identified. The following parts explain options for reform and assess how the various alternatives perform when assessed against the aforementioned criteria.

\section{Options for Reform}

\section{A The Judicature Modernisation Bill}

The Judicature Modernisation Bill, presently before Parliament, arose following a report by the Law Commission. For judicial appointments the Commission endorsed the status quo system but made recommendations designed to increase its transparency and ensure consistency in its application. ${ }^{153}$ Several of these recommendations were not included in the subsequent Judicature Modernisation Bill, but with little explanation for their omission. It is suggested here that the Commission's

152 See McCormick, above n 29, at 2.

153 Law Commission, above n 63, at Recommendations 12-17. 
recommendations are valuable but that they are insufficient alone to respond to the issues raised in this paper.

\section{$1 \quad$ Law Commission Recommendations}

One recommendation that was accepted by the Government would require the Attorney-General to publish the process he or she would follow in soliciting and advancing nominations for judicial appointment. ${ }^{154}$ A second recommendation concerned the consultation of interested parties when appointing judges. The Commission recommended the following: ${ }^{155}$

Before making an appointment, whether "first instance" or an elevation to a higher court, the Attorney-General should be required by statute to consult:

o the Chief Justice, in the case of an appointment to the Higher Courts, and the Chief District Court Judge, in the case of appointment to the District Courts;

0 the Head of Bench of the court to which the appointment will be made;

0 the Solicitor-General;

o the President of the New Zealand Law Society;

o the President of the New Zealand Bar Association; and

0 such other persons as he or she considers to be appropriate.

Notably, this recommendation includes the words "whether 'first instance' or an elevation to a higher court". Their inclusion accords with the view of many submitters to the Commission, who saw the process of consultation as being of equal, if not greater, importance for judicial elevations as for the initial appointment. ${ }^{156}$ The Law Society, for example, said that the profession has "a vital interest" in promotions, and "is likely to have information that would be of substantial importance in making promotions". ${ }^{157}$ The Commission was of the view that this would not create an undue administrative burden on those involved as relatively few appellate appointments are made each year. ${ }^{158}$

154 Law Commission, above n 63, at Recommendation 15. See Judicature Modernisation Bill 2013 (178-2), cl 93.

155 At Recommendation 17.

156 At [5.26]-[5.27]. Submitters of this view included the New Zealand Law Society, the New Zealand Bar Association, the Chief District Court Judge and the Senior Courts' Judges.

157 Law Commission, above $\mathrm{n}$ 63, at [5.27].

158 At [5.28]. 
It is appropriate that the Commission considered elevations to be equally as important as initial appointments. Elevations to higher courts are particularly significant and likely to attract the most attention if a supreme law BORA were enacted, given that decisions striking down legislation are likely to be appealed to the Supreme Court. The quality and political neutrality of appeal court appointments is therefore essential.

While recognising that no single template is achievable or desirable for New Zealand judges, the Commission also suggested some general principles that an AttorneyGeneral ought to observe in making appointments ${ }^{159}$ and recommended that criteria for appointment be included in statute. ${ }^{160}$

\section{Inadequacy of the Judicature Modernisation Bill}

The Ministry of Justice, in a document explaining the Judicature Modernisation Bill's changes to judicial appointments, accepted that "scope exists to achieve greater clarity and transparency in the judicial appointment process, given the limited publicly available information". ${ }^{161}$ Despite this recognition, the Bill is significantly less comprehensive than the Commission proposed. The Bill does not require that consultation take place and does not include a list of the people to be consulted, and nor are criteria for appointment to be codified. Instead, cl 93 of the Bill only sets out a requirement for the publication of information concerning the appointment process: ${ }^{162}$

\section{Attorney-General to publish information concerning judicial appointment process}

The Attorney-General must publish information explaining his or her process for-

(a) seeking expressions of interest for the appointment of Judges and Associate Judges; and

(b) recommending persons for appointment as a Judge or an Associate Judge.

While this is a welcome change, and reflects one of the Commission's recommendations, it falls well short of what was suggested. Yet there has been very

159 At [5.43].

160 At Recommendation 16.

161 Office of the Minister of Justice, Cabinet Social Policy Committee "Government response to the Law Commission's Report: Review of the Judicature Act 1908: Towards a New Courts Act" (Ministry of Justice, Wellington, April 2013) at [31].

162 Judicature Modernisation Bill 2013 (178-2), cl 93. 
little explanation for, or discussion of, these omissions. A response to the Commission's Report from the Minister of Justice said: ${ }^{163}$

However, I do not support placing relatively detailed appointment criteria and consultation in primary legislation, as proposed by the Commission. Instead, after consultation with the Attorney-General, I propose a legislative requirement for the Attorney-General to produce public guidelines or protocols outlining the process to be followed when he or she solicits and advances judicial appointment recommendations to the Governor-General

My approach enables transparency and flexibility, and reinforces the public protocol that has already been approved by the Attorney-General for District Court judicial appointments. An equivalent protocol is soon to be made available for higher courts appointments in line with the proposed statutory requirement.

The only explanation for this change is suggested by the use of the term "flexibility", which accords with the view of some submitters to the Commission that desirable flexibility is lost if the criteria for judicial appointment are codified. ${ }^{164}$ Despite this, the majority of submitters to the Commission agreed that there should be statutory criteria, ${ }^{165}$ and submitters almost unanimously agreed with the other significant proposal - that consultation with specified individuals should be mandatory and formalised in legislation. ${ }^{166}$

There is therefore little to explain the change. Nor has clarification been forthcoming as the Bill progressed through the House; there has been no discussion or criticism of the failure to include the Commission's more comprehensive recommendations. Clause 93 attracted cross-party support in the First Reading debate ${ }^{167}$ and was unchanged by

163 Office of the Minister of Justice, above n 161, at [31]-[32].

164 Law Commission, above n 63, at [5.42]. This was the view of the Senior Courts' judges and two law firms, one of which suggested that "the Attorney-General will become tied down to particular criteria at the expense of taking a more rounded view of the merits of the particular individual (including the views of those with whom the Attorney-General has consulted)".

165 Law Commission, above n 63, at [5.43].

166 Law Commission, above n 63, at [5.54]-[5.55].

167 (5 December 2013) 695 NZPD 15304-15309 per Raymond Huo (who said cl 93 will "enhance transparency"); David Clendon (who called cl 93 a "very healthy contribution to transparency"); and Denis O'Rourke (who suggested that "the public will welcome" cl 93). 
the Select Committee. ${ }^{168}$ It remained unaltered despite the Attorney-General and others pointing out that that Select Committee would "need to look very carefully" at c1 93. ${ }^{169}$

Given that the Bill is lengthy and concerns a topic that is unlikely to attract the public's attention, it appears that MPs are paying it little attention. ${ }^{170}$ The lax attitude towards the Commission's recommendations is problematic given the constitutional importance of judicial appointments. It is unfortunate that the Commission's measured reforms, which would enhance the transparency of the appointments process and ensure greater consistency in its application, were largely rejected without sufficient explanation.

Although the changes are welcome, and are an appropriate response to current concerns about judicial appointments, they are not sufficient to address the issues raised in this paper because the Attorney-General would retain wide discretion over appointments. The subdued nature of the recommendations was recognised by the Commission; its focus was "a modest consolidation project". ${ }^{171}$ Therefore, it is necessary to go beyond the Judicature Modernisation Bill to seek more comprehensive options for reform.

\section{B Election}

Although some jurisdictions, notably many American states, opt to elect judges, this undermines the independence of the judiciary and with it the rule of law. Election is unlikely to be favoured in New Zealand and can be dismissed as a legitimate option for reform. Friedland, although writing in the Canadian context, aptly described the case against electing judges: ${ }^{172}$

Few things would be more destructive of the independence of the judiciary than to have judges campaign for office accepting contributions to pay for their campaigns, let alone having to run on a law-and-order platform.

168 Judicature Modernisation Bill 2014 (178-2) (select committee report).

169 (5 December 2013) 695 NZPD 15302 per Christopher Finlayson; also see (5 December 2013) 695 NZPD 15310 per Scott Simpson who commented that cl 93 "will be a matter that the committee wants to pay attention to".

170 See the comments of Phil Goff which suggest that a deferential approach is being taken due to the involvement of the Law Commission; (5 December 2013) 695 NZPD 15311.

171 Law Commission, above n 63, at [5.32].

172 Friedland, above n 29, at 58. 


\section{Formal Training}

Similarly the civil law model where judges are formally trained in a separate career path to lawyers will not be adopted. New Zealand's common law tradition, where most judges have had at least 15 years of experience in legal practice, is very likely to be retained in the future. Any reform must conform to this tradition.

\section{Public Legislative Hearings}

Legislative hearings at which nominees are questioned by elected representatives take place in Canada and the United States. Under this reform, the present system of appointment would be retained but a candidate selected by the Attorney-General would appear before a committee of MPs, most likely the Justice and Electoral Select Committee, prior to being officially appointed by the Governor-General. The varying forms that legislative hearings could take are discussed below, but ultimately it is contended that public hearings are not a desirable reform.

The American model for Supreme Court confirmation hearings should not be adopted in New Zealand. Given that the hearings are conducted publicly and Senators can block a Supreme Court nominee, the hearings are characterised by aggressive questioning and politicking. ${ }^{173}$

An alternative model, adopted in Canada, is a public hearing at which MPs question appointees but cannot vote. The fact that MPs cannot vote on the nomination "lowers the temperature" of the hearing and purportedly makes the occasion less politicised. ${ }^{174}$ However, because a government can insist on its nominee regardless of the hearing's outcome, the process comes across as superficial rather than as a real check on the Attorney-General. As MPs could not vote to show their opposition to a candidate, they are more likely to publicly express their concerns, which would be damaging to the candidate if they were nevertheless appointed.

Furthermore, the absence of voting is no guarantee that MPs would behave appropriately. Although the first Canadian hearing was conducted politely, in 2011 SCC appointee Michael Moldaver was subjected to "glib and disrespectful challenges"

173 Hausegger, Hennigar and Riddell, above n 95, at 142.

174 Hogg, above n 94, at 532. 
concerning his inability to speak French; he was asked over five times about this issue and was asked one question in French, an approach surely meant only to embarrass him. ${ }^{175}$ The presence of a Canadian constitutional expert moderating the session did not prevent these sorts of attacks. Unfortunately, New Zealand's political culture and the ubiquity of inflammatory rhetoric means that MPs would be likely to behave similarly and undermine the value of the process, using it as an opportunity to score political points. Therefore, public legislative hearings in either the American or Canadian model should not be adopted in New Zealand.

\section{Private Confirmation}

Given the problems associated with public confirmation hearings, an alternative reform would create a private process through which an individual or group confirms the suitability of the appointment. Under this model, the Attorney-General would nominate one individual for judicial appointment, with the same consultative process as is presently adopted. His or her nominee would be appointed by the GovernorGeneral only if the individual or committee confirmed the appointment. If the nomination was rejected, the Attorney-General would be required to submit a new candidate.

\section{A Composition}

Approval of the Attorney-General's nomination could come either from a Judge, a group of MPs, or a specifically constituted committee. The Law Commission raised the possibility that the concurrence of the Chief Justice or relevant Head of Bench could be required, creating a judicial veto over appointments. ${ }^{176}$ The problem with this approach is two-fold; first, a judicial veto risks self-perpetuation within the judiciary given the inclination among judges towards more conservative choices, and secondly, it does too little to enhance the transparency and democratic legitimacy of the process.

An alternative would require the nominee to appear before a private confirmation hearing conducted by MPs - likely the Justice and Electoral Select Committee. The

175 Emmett Macfarlane "Why public hearings with Supreme Court nominees should mean something" Macleans (20 October 2011) <www.macleans.ca>

176 Law Commission, above n 63, at [5.33]. 
absence of public exposure would reduce the incentive for politicking, permitting a more productive session than the previously discussed public hearings.

However, if the governing party and its support partners held a majority on the Select Committee, the process may lack the necessary rigour to create a real check sufficient to stop political opponents from publicly criticising appointments. A group of MPs may also give weight to peripheral considerations rather than the candidate's legal ability and suitability for appointment. For example, Justice Rothstein derived support from Canadian MPs for being "very 'judge-like'"177 and for "his informality, selfdeprecating sense of humour, and willingness to explain his judicial philosophy in simple terms". ${ }^{178}$

The involvement of a number of MPs also increases the risk that information would be leaked to the media if politically expedient, particularly if a minority of the committee members were opposed to the nominee. The heightened risk of leaks is problematic as it may deter good candidates from seeking judicial office.

A third option is the creation of a specifically constituted committee responsible for approving the Attorney-General's decision. This committee would be likely to include the Chief Justice and Solicitor-General, as representatives of the bench and bar, and could include lay members and MPs.

\section{B Advantages and Disadvantages}

Retaining the Attorney-General as the primary decision-maker will be seen by proponents of this model as its main advantage. Ministerial responsibility is not diluted so the conventions that presently govern appointments can continue to operate, but with a genuine check on the Attorney-General's exercise of discretion. The committee could also provide feedback to the Attorney-General if it were concerned about, for example, the homogeneity of appointments. The committee's voting power and ability to reject a candidate means that it cannot be dismissed as a mere process of rubber stamping.

177 Hausegger, Hennigar and Riddell, above n 95, at 143.

178 Ziegel, above n 123, at 549. Also see Hogg, above n 145, at 426. 
However, the central role of the Attorney-General is also this proposal's main weakness. One of the main problems with the present system is the concentration of decision-making power in one person. It is hard to justify why one individual, even a government minister, should have this level of influence over the judiciary's composition, especially when judges' powers are substantially wider under a supreme law BORA. This reform does too little to change that. Because the committee cannot propose individuals for appointment, but can solely approve or reject the AttorneyGeneral's nomination, its influence is fairly limited.

The process is also likely to be seen as insufficiently independent of the government to enhance the perception that judicial appointments are politically neutral and quell political attacks on appointees. Although the involvement of MPs would add to the non-political nature of appointments, given the weakness of the committee this is insufficient to nullify concerns about the government's control of the process. Thus the benefit of this proposal, that it retains aspects of the present system which work well, is also its main drawback. The committee is too weak to sufficiently balance the power of the Attorney-General.

\section{Appointments Commission}

An appointments commission is a prominent option for reform; commissions have been adopted with increased frequency offshore, notably in the United Kingdom. ${ }^{179} \mathrm{~A}$ commission has been proposed in New Zealand on several occasions, first by the 1978 Royal Commission on the Courts, whose suggestion was opposed by the judiciary and

179 For example Jowell, above n 82, argues that there is a growing global consensus in favour of the use of judicial appointments commissions. In the United Kingdom, the Judicial Appointments Commission is responsible for appointments to courts and tribunals in England and Wales, and for some tribunals whose jurisdiction extends to Scotland or Northern Island. This is referred to in this paper as the appointments commission for England and Wales. It should be noted that a separate commission operates for many Scottish judicial appointments. Further information on the Scottish model can be found in Alan Paterson "The Scottish Judicial Appointments Board: New Wine in Old Bottles?" in in Kate Malleson and Peter H Russell (eds) Appointing Judges in an Age of Judicial Power: Critical Perspectives from around the World (University of Toronto Press, Toronto, 2006) 13. 
was not enacted. ${ }^{180}$ In the 1990s the idea resurfaced and derived support from Sir Robin Cooke, then President of the Court of Appeal, and Sir Thomas Eichelbaum, then Chief Justice. ${ }^{181}$

The issue arose again in 2004. A number of submissions on the legislation creating the Supreme Court expressed distrust of the existing system and supported the formation of a judicial appointments commission. ${ }^{182}$ Although the Ministry of Justice produced a consultation paper on the matter, ultimately this idea was not pursued. ${ }^{183}$ Then Attorney-General Margaret Wilson is still supportive of the creation of an independent body to recommend appointments. ${ }^{184}$

\section{A Appointing or Recommending Commission}

There are broadly two models that an appointments commission could adopt. Under the first, the commission has total responsibility for the appointment and would directly advise the Governor-General on the candidate to be appointed. The second, which is adopted more commonly overseas, operates as a recommending commission, which produces a shortlist from which the Attorney-General selects whom to appoint. ${ }^{185}$

The primary disadvantage of the first model, where the Attorney-General is not involved, is the reduction in accountability to Parliament. Former Chief Justice of Australia, Sir Anthony Mason, suggested that: ${ }^{186}$

180 See "Report of the Royal Commission on the Courts" [1978] AJHR H2 at 200-202. The proposed commission would have comprised the Chief Justice, the Chief District Court Judge, the SolicitorGeneral, the Secretary for Justice and two New Zealand Law Society nominees.

181 Joseph, above n 25, at [21.4.1(3)]. See also Cooke, above n 32, at 1331; and Eichelbaum, above n 81 , at $427-429$.

182 Ministry of Justice, above n 46, at [16]. See also Joseph, above n 28, at 70.

183 Ministry of Justice, above n 46.

184 Wilson, above n 49, at 48.

185 Straw, above n 36, at 57.

186 Anthony Mason "The Appointment and Removal of Judges" in Helen Cunnningham (ed) Fragile Bastion (Judicial Commission of New South Wales, Sydney, 1997) 1 at 16-17. See also Robert Stevens The English Judges: Their Role in the Changing Constitution (Hart, Oxford, 2002), who suggests at 144 that "[j]udges choosing judges is the antithesis of democracy". Similarly, James 
... there is a powerful democratic argument against transferring the power of appointment away from the executive government to a commission consisting of persons who are not elected by the people. One justification for the exercise of judicial power by non-elected Judges in a democracy is that the Judges are indirectly appointed by the people in that it is the duly elected government that makes the appointments. That is a very important argument which tells against entrusting the power of appointment to others, whatever the advantages may be of pursuing such a course.

Although arguing against an appointments commission, Mason's statement suggests that, if a commission is implemented, involving the Attorney-General in some capacity is necessary to avoid an undesirable reduction in democratic legitimacy. This is particularly important given the heightened need to protect the democratic legitimacy of judges who are able to strike down laws passed by Parliament. Although the inclusion of MPs on the commission would impart some responsibility to Parliament, this alone would provide weaker accountability than the direct ministerial responsibility created by the Attorney-General's involvement.

The concern in the United Kingdom, which could apply equally in New Zealand, was that by removing the Lord Chancellor from appointments, he or she would "cease to operate so effectively as a bridge between the judiciary and Government". ${ }^{187}$ Removing the Attorney-General from the appointments process may also make him or her less inclined to defend the judiciary against criticism. ${ }^{188}$ Therefore, given the tension that exists between creating a body which is independent of government while still ensuring accountability to Parliament, a commission with total responsibility for appointments errs too far towards independence at the expense of accountability.

The recommending commission model also has benefits when considering the quality of candidates appointed for judicial office. Critics of an appointments commission have expressed concern that it will encourage the appointment of conventional, compromise candidates. ${ }^{189}$ In contrast, the Attorney-General is well placed to make unconventional appointments and choose candidates with unorthodox backgrounds

Allan suggests that the appointments commission for England and Wales does not have "even a modicum of democratic legitimacy", see Allan, above n 93, at 78.

187 Ministry of Justice The Governance of Britain: Judicial Appointments (October 2007) at [4.15].

188 Ministry of Justice, above n 187, at [4.15].

189 See Stevens, above n 186, at 144; and Allan, above n 10, at 110. 
because he or she has the benefit of seeing the courts in their wider social and political context. ${ }^{190}$ This issue is a particular problem given the increased importance of diversity of experience among judges once a supreme law BORA is enacted. Tasking the commission with the creation of a shortlist, rather than recommending a single name, goes some way to mitigating this concern by ensuring greater scope for the commission to select individuals other than the most obvious and conventional candidates.

Furthermore, Malleson contends that the risk of compromise appointments is predominantly of concern in highly politicised appointments systems. There is evidence from commissions in the United States of "the rejection of dynamic, higherrisk candidates in favour of bland, safe appointments". ${ }^{191}$ However, she contends that this situation must be seen in context. As American appointments commissions have usually replaced a system of electing judges, and as commission members are typically divided along political lines, the selection of compromise candidates often results. Thus Malleson argues that the risk of a similar outcome in countries that do not have an underlying culture of politicised appointments is remote. ${ }^{192}$

One contentious matter is whether the Attorney-General should be bound to accept the commission's shortlist. Eichelbaum suggested that the Attorney-General should be free to make an appointment from outside the commission's shortlist, but that this would need to be publicly notified. ${ }^{193}$ However, this approach undermines the value of the reform, given that the predominant concern with the present system is that there are too few formal checks on the Attorney-General. It is instead preferable to require the Attorney-General to select a candidate from the commission's shortlist, but he or she should be able to ask the commission to reevaluate its recommendation. The grounds on which the Attorney-General can ask for reconsideration should be clearly established and reasons for the decision should be required. ${ }^{194}$ A shortlist of three

190 Palmer, above n 8, at 82. Also see the discussion of this issue in Straw, above n 36, at 75.

191 Kate Malleson "The New Judicial Appointments Commission in England and Wales: New Wine in New Botttles" in Kate Malleson and Peter H Russell (eds) Appointing Judges in an Age of Judicial Power: Critical Perspectives from around the World (University of Toronto Press, Toronto, 2006) 39 at 45.

192 Malleson, above n 191, at 45.

193 Eichelbaum, above n 81, at 429.

194 See Kate Malleson "Creating a Judicial Appointments Commission: Which Model Works Best" [2004] Public Law 102 at 113 for a further discussion of this matter. 
names would be appropriate; fewer than three names places too significant a limit on the Attorney-General, while allowing more than three names risks undermining the value of the commission as a limit on the exercise of discretion.

\section{B Composition}

A commission's composition and how its members are to be appointed are two of the most contentious issues regarding appointments commissions. In particular, there is concern that appointments to the commission may themselves become politicised and that the commission will be unduly dominated by judges, leading to self-replication within the judiciary. The following discussion explains these concerns and contends that the composition of the commission can alleviate them.

\section{$1 \quad$ Political Appointments to the Commission}

Critics suggest that appointments to the commission itself may become politicised. They are concerned that the political element could simply shift and operate in a more covert manner; members of the government may attempt to stack the commission to ensure their preferred candidates are selected. ${ }^{195}$

This situation appears to have occurred in Canada, where appointments commissions are used for federal judicial appointments below the SCC level, and in many provinces. In 2006 the federal government added a police representative to each commission, which was seen as an attempt to ensure the appointment of "tough on crime" judges. ${ }^{196}$ The judicial representative was also restricted from voting except in cases of a tie. This gave the government the power to appoint a majority of the voting members of the commission and was heavily criticised. ${ }^{197}$ These changes illustrate the need for a bipartisan approach to reform, to avoid as much as possible later alterations of the commission's composition.

The appointments commission for England and Wales attempts to alleviate concerns about the way members are appointed but in an administratively burdensome way.

195 Palmer, above n 8, at 82; East, above n 9, at 190.

196 Friedland, above n 29, at 55.

197 Friedland, above n 29, at 55-56. For example, the Canadian Judicial Council said that the reform "puts in peril the concept of an independent body that advises the government on who is best qualified to be a judge". 
Their 15-person commission is comprised of six lay people, five judges (taken from the different levels of court), one solicitor, one barrister, and two lay judges (one magistrate and one tribunal member). ${ }^{198}$ The three most senior judicial members are appointed by the Judges' Council, while other commissioners are appointed by the Lord Chancellor after consultation with an advisory body comprising the Lord Chief Justice, the chair of the Commission and an additional lay member appointed by the Minister. ${ }^{199}$ While this diminishes concerns about politicised appointments to the commission, creating a separate advisory committee responsible for appointing members of the appointments commission is cumbersome. The high administrative burden is exacerbated by New Zealand's small size and comparatively limited resources.

A better and simpler solution is for individuals to sit on the commission by virtue of another office they hold. Rather than making specific appointments to the commission, the Solicitor-General for example would automatically become a member by virtue of being Solicitor-General.

The Ministry of Justice's 2004 Consultation Paper suggested the following composition for a commission: ${ }^{200}$

- Three lay people, who are not practising lawyers and have never held judicial office;

- The Chief Justice (or nominee, who is a judge);

- One other senior judge (for example the Chief Judge of the Court in which the vacancy occurs);

- The President of the New Zealand Law Society (or nominee);

- The President of the New Zealand Bar Association (or nominee); and

- One of the following persons: ${ }^{201}$

- The Solicitor-General (or Deputy Solicitor-General);

- The Secretary of Justice (or nominee);

○ The Chief Executive of Te Puni Kōkiri (or nominee).

198 Constitutional Reform Act 2005 (UK), sch 12.

199 Sophie Turenne "Judicial Independence in England and Wales" in Anja Seibert-Fohr (ed) Judicial Independence in Transition (Springer, Heidelberg, 2012) 147 at 158-159.

200 Ministry of Justice, above n 46, at [78]-[79].

201 The Consultation Paper proposed that the individual involved would depend on whether the appointment was to the superior courts (Solicitor-General); the District Court, including the Family and Youth Courts and the Employment and Environment Courts (Secretary of Justice); or the Māori Land Court (Chief Executive of Te Puni Kōkiri). 
The majority of these individuals would sit on the appointments commission by virtue of another role, whether as a senior member of the judiciary, a public servant, or as head of one of the legal associations. This circumvents the difficulties that arise when deciding which individuals, for example which judges or bar representatives, should be included.

However, problems arise in respect of lay members. Given the aforementioned risk of politicised appointments, it is not desirable for the government to appoint three lay members to the commission, as proposed in the 2004 Consultation Paper. One solution would be for lay members to also be appointed by virtue of an office they hold; for example, the Auditor-General or an Ombudsman could be members of the commission. It is suggested here that a better solution is for no lay members to sit on the commission.

\section{$2 \quad$ Lay Members}

Many appointments commissions include a number of lay members, with some comprised of a majority of lay members while other are chaired by a lay member. ${ }^{202}$ The argument for including lay members is that they bring fresh ideas and perspectives to the commission to balance the influence of judges who may otherwise dominate its decisions and encourage self-replication within the judiciary. ${ }^{203}$

Others hold a contrary view; that the commission will be captured by judicial representatives, leading to safe and conservative picks. ${ }^{204}$ Palmer, for example, expressed concern that judges who sat on the commission would exert great weight on the opinion of lay members, suggesting this risks "turn[ing] the judiciary into a self perpetuating oligarchy". 205

A better mechanism for balancing the influence of judicial representatives is the inclusion of representatives from the bar. The Solicitor-General and Presidents of the

202 See Malleson, above n 191, at 48.

203 Malleson, above n 191, at 48.

204 See East, above n 9, at 190; and Palmer, above n 8, at 81-82. Allan has expressed a similar concern regarding the appointments commission for England and Wales; see Allan, above n 93, at 80.

205 Palmer, above n 8, at 82. Allan similarly expressed concern that the appointments commission for England and Wales would promote the appointment of "an insulated, self-selecting lawyerly caste"; see Allan, above n 93, at 81. 
Bar Association and Law Society are less likely to be unduly influenced by judges on the commission precisely because they are not lay members. As legally trained representatives of the bar they are well-positioned to assess the legal ability of candidates, for example the quality of the legal reasoning in their judgments, whereas lay members may be more likely to defer to judicial representatives on these matters.

\section{$3 \quad$ Members of Parliament}

Members of Parliament should sit on the commission, as occurs in several countries including South Africa and Israel. ${ }^{206}$ As the central democratic authority, Parliament has a valid interest in judicial appointments, particularly when judges have the ability to strike down legislation. Malleson contends that including MPs on a commission increases democratic accountability and hence the legitimacy of the process. ${ }^{207}$ It would be likely to also increase the democratic legitimacy of judges in the eyes of the public. Canada's experience showed a strong desire for MPs to be involved in appointments post-Charter. If legislative hearings are not implemented in New Zealand - and there are good policy reasons why they should not be - another mechanism should be established for involving MPs.

Shutting MPs out of the process also runs counter to the goal of limiting political eruptions or sensations in response to appointments and unpopular judgments. Without their inclusion, the commission is at risk of being viewed as too insular as all members would be part of the legal establishment. Thus by increasing the democratic legitimacy of the judiciary and reducing the likelihood of politicised attacks on judicial appointments, there are reasons of both principle and pragmatism for including MPs on the commission.

The view that the commission should not include lay members strengthens the argument for including MPs. Like the Attorney-General, MPs see the courts within their broader social and political context, which may direct the commission towards more unorthodox appointments. Including MPs on the commission also further mitigates the risk of disproportionate judicial influence.

206 Malleson, above n 194, at 118.

207 Malleson, above n 194, at 118. 
Critics will point out that MPs already have the ability to oversee appointments and could, for example, conduct a Select Committee examination of the appointments process. However, the fact that this mechanism has not been used does not mean that MPs will be unconcerned about appointments in future. Once judges are able to strike down laws enacted by Parliament, the interest in appointments and demand for involvement is likely to substantially increase, as was the case in Canada.

As with the previously discussed reforms, the involvement of MPs increases the risk that confidential information may be leaked. Compared with a post-appointment legislative hearing, the risk is lower here because fewer MPs are involved. While this concern still exists, it is managed and outweighed by the benefit brought by their inclusion.

\section{The Case for an Appointments Commission}

The forgoing discussion illustrates how several of the most common critiques of an appointments commission - that it will be captured by judges, or that appointments to the commission will be politicised - can largely be mitigated by its composition. Drawing on that discussion and other considerations, this section contends that an appointments commission is the best option for New Zealand.

The primary advantage of the commission is that it enhances the political neutrality of appointments by shifting decision-making power away from a member of the government to an independent body. At present, the political neutrality of the process will inevitably be questioned, regardless of how impartial appointments are in practice, because a government minister has largely unchecked control over appointments. ${ }^{208}$ Shifting responsibility to an independent commission therefore achieves two of the main policy goals; it creates a genuine check on the Attorney-General, reducing his or her ability to stack a court with ideological appointments, and enhances the perception that this will not occur.

An appointments commission is more effective in this regard than a form of committee confirmation. Under that model, the committee is too weak to effectively balance the Attorney-General's power over the process.

208 See Jowell, above n 82, at 3. 
Another advantage of an appointments commission is its transparency and inclusiveness. Legislative hearings offer transparency because they are open to the public. The transparency of an appointments commission is of a different nature; it is derived from the commission providing an inclusive, consistent process which operates independently of the government for both appointments and elevations. This is a significant benefit in a society that questions authority figures and demands more transparency. ${ }^{209}$

The existing system does not seek to elicit support for appointments from members of the legislature whose laws would eventually be reviewed. ${ }^{210}$ With a supreme law BORA this weakness becomes more significant, given the risk that judges may be viewed as too powerful compared to elected representatives. Involving MPs is valuable because it elicits Parliament's support for appointments without creating the problems associated with legislative hearings. This also reduces the risk that political actors will publicly attack or sensationalise appointments and the appointments process.

Some commentators argue that a commission will not remove the risk of politicised appointments. Their concern is that a shortlist created by an advisory commission "does not diminish or curtail patronage, but 'aids and abets' it by supplying the [member of the executive] with cover to take partisan considerations into account". ${ }^{211}$ Palmer and East both expressed concern about the division of responsibility and corresponding lack of accountability that an appointments commission brings. ${ }^{212}$ It is easier to question the propriety of a discretionary appointment made by one person than to question the decisions of an ostensibly independent commission, where the division of decision-making power means that accountability can be offloaded to others involved. ${ }^{213}$

This is a legitimate concern, but needs to be weighed against the countervailing desirability of creating a more open and inclusive appointments process. By spreading

209 See Eichelbaum, above n 81, at 421.

210 Jowell, above $\mathrm{n} 82$, at 3.

211 Gee, above n 33, at 107. Also see FC DeCoste "Political Corruption, Judicial Selection and the Rule of Law" (2000) 38 Alta L Rev 654 at 675.

212 Palmer, above n 8, at 82; and East, above n 9, at 190.

213 Allan, above n 10, at 116. 
the decision-making power among a group of people, inevitably the accountability of each individual is reduced. That is the cost of a more inclusive and transparent system.

Furthermore, even if political factors did affect the Attorney-General's selection from the shortlist, the commission's value would not be negated. As discussed above, complete impartiality is impossible as there are some political matters which will inevitably factor into appointments. The value of the commission is that the political element is managed and limited. An Attorney-General would not be able to stack the court with ideologically driven candidates; to be included on the shortlist, the commission must have confirmed that a candidate is well qualified. Thus, regardless of which individual is selected from the shortlist, and the reasons for that decision, the public and Parliament can be confident that the appointee is suitable.

Proponents argue that an appointments commission will increase diversity on the bench. ${ }^{214}$ While some commentators contend that the appointments commission for England and Wales has successfully increased diversity, ${ }^{215}$ others argue that this reform is not a panacea for increasing diversity. Sundeep Iyer found an increase in female appointments in the first year of the commission's operation, but that this increase vanished shortly thereafter. ${ }^{216}$ Creating a commission was not itself enough to address concerns about a lack of diversity; commissions are "not the cure that politicians have sought ". ${ }^{217}$

Instead, sustained initiatives directly targeted towards this issue are necessary if greater diversity is to be achieved. For example, in Ontario the appointments commission directed that a letter be sent to all 1,200 senior women lawyers in the province asking

214 See the discussion in Malleson, above n 191, at 42-44.

215 Baroness Usha Prashar "Translating Aspirations into Reality: Establishing the Judicial Appointments Commission" in Judicial Appointments: Balancing Independence, Accountability and Legitimacy (Judicial Appointments Commission, 2010) 41 at 51-52.

216 Sundeep Iyer "The fleeting benefits of appointments commissions for judicial gender equality" (2013) 51 Commonwealth and Comparative Politics 97. Also see Kate Malleson "Diversity in the Judiciary: The Case For Positive Action" (2009) 36 Journal of Law and Society 376 for similar findings on the failure of the appointments commission for England and Wales to increase diversity as hoped.

217 Iyer, above n 216, at 117. Commenting on the appointments commission for England and Wales, Straw similarly said that "[t]he assumption regarding diversity - naïve, as it turned out - was that if we changed the process, we would change the outcome"; Straw, above n 36, at 54. 
them to consider applying for judicial office. This produced a marked increase in the number of female applicants. ${ }^{218}$ Thus targeted initiatives towards increasing diversity are likely to be more effective than simply changing the method of appointments. Given the divergence of academic opinion, increasing the diversity of the bench does not provide a strong argument either in support of or against of an appointments commission.

However, concerns that an appointments commission will give judges undue influence and impede the appointment of unconventional candidates are mitigated by the composition and powers of the proposed commission. The inclusion of MPs and bar representatives is likely to balance judicial influence. Furthermore, the fact that the commission's responsibility is to create a shortlist rather than recommend a single name ensures greater scope for the commission to select unorthodox candidates.

The cost and administrative burden of an appointments commission is often cited as a disadvantage. ${ }^{219}$ The appointments commission for England and Wales, responsible for nominating more than 700 judges each year, has 15 commissioners and a significant support staff. ${ }^{220}$ Its total expenditure in $2013 / 14$ was $£ 5.59$ million. ${ }^{221}$ In contrast, New Zealand appoints about 12 judges annually. ${ }^{222}$ Yet despite the differences in size, concerns about ensuring neutrality and increasing transparency are equally important in New Zealand as in the United Kingdom.

It is indisputable that an appointments commission would impose administrative burdens on those involved, which would need to be supported with sufficient

218 Malleson, above n 191, at 43.

219 Law Commission Review of the Judicature Act 1908: Towards a Consolidated Courts Act (NZLC IP29, 2012) at [3.20].

220 Law Commission, above n 219, at [3.20].

221 Judicial Appointments Commission Annual Report and Accounts (2013/14).

222 Law Commission, above n 63, at [5.22]. 
appropriations. ${ }^{223}$ However the low number of appointments annually eases the burden on members, most of which are already involved with appointments to some degree. ${ }^{224}$

\section{Administrative Aspects}

This section outlines some administrative matters which would contribute to the success of an appointments commission in New Zealand. The initial process could be managed by the Solicitor-General, as currently occurs. Similar levels of consultation, with members of the commission and those outside it, would ensure that a wide range of candidates was considered. In consultation with the members of the commission, a database of qualified candidates would be created. The primary responsibility of the commission would then be reviewing this database to create a shortlist of three candidates.

Palmer proposed the creation of an office within Crown Law, headed by a new Deputy Solicitor-General, to provide support on judicial appointments. ${ }^{225}$ The functions of the office would include calling for expressions of interest, holding confidential files on future candidates, managing the interview process and conducting referee checks. Although this was recommended in the context of the present appointments system it could equally be adopted as the administrative and support component of an appointments commission.

There should be provision for two MPs to sit on the commission. To ensure that the MPs are seen as representing Parliament, one should be drawn from within the governing parties and one from within the parties in opposition. The statute could provide that two MPs are to be designated members of the commission by the Prime Minister and by the Leader of the Opposition. Although it is likely that those appointed would be legally qualified, this should not be required as other experience, for example in making other public appointments, would also be valuable. Commentary on the

223 See Supreme Court, Court of Appeal and High Court "Submission on the Judicature Modernisation Bill" (2014) at [8], which expressed concern at additional administrative requirements being imposed on the Chief Justice and others which were not being supported by sufficient resource allocations.

224 The exceptions to this are the two MPs, although the shadow Attorney-General and chairperson of the Justice and Electoral Select Committee may be consulted under the existing appointments process, see Ministry of Justice, above n 49.

225 Chen Palmer \& Partners, above n 23, at [7]-[17]. 
legislation could suggest that the shadow Attorney-General and chairperson of the Justice and Electoral Select Committee should be considered for appointment first; they are obvious candidates for inclusion as both tend to be consulted during the existing judicial appointments process.

The appointments commission should operate for appointment and elevations to all courts, as was suggested in the 2004 Consultation Paper. ${ }^{226}$ Some flexibility in the commission's composition is necessary to accommodate the burden that it places on its members, so the commission's membership would partly depend on the court in which the vacancy arose. The Consultation Paper proposed a desirable degree of flexibility in recommending that in addition to the Chief Justice, the second judge involved would vary and could be the head of the bench of the court in which the vacancy occurs. ${ }^{227}$ Given the administrative burden, this is preferable to requiring the various heads of bench to all sit on the commission for all appointments. The Consultation Paper also suggested that commission members could nominate another individual to take their place; this is necessary because it would be unreasonable to expect the Chief Justice, for example, to sit on the commission for all judicial appointments.

\section{Conclusion}

The enactment of a supreme law BORA in New Zealand would enhance the importance of judicial independence and lead to increased scrutiny of the method of appointing judges. Canada's experience after enacting the Charter indicates that New Zealand's existing appointments system will need to be reformed. The present appointments process lacks transparency, can operate in an ad hoc manner, and gives wide discretion to the Attorney-General, whose integrity is the main safeguard against improperly political appointments. Given the increased incentive for politicised appointments under a supreme law BORA, this process does not sufficiently protect the neutrality of appointments.

The latter parts of this paper evaluated alternative methods of appointing judges. The Canadian case study suggests that any reform adopted must be proactive, codified,

226 Ministry of Justice, above n 46, at [5]; see the discussion at [6]-[7] about proposed exceptions to this general process, for example for temporary appointment of former judges.

227 For Supreme Court vacancies, a second Supreme Court judge, or another Judge who was not being considered for elevation to the Supreme Court, could sit on the Commission. 
bipartisan and responsive to the issues raised. Reform of judicial appointments should aim to increase public confidence in the independence and democratic legitimacy of the judiciary, provide safeguards to prevent improperly political appointments and, to reduce the risk of public attacks on the judiciary, enhance the perception that political appointments will not occur.

The forgoing discussion showed that several of the criteria by which appointments systems were assessed are in tension, for example reform that enhances independence from the government inevitably reduces accountability to Parliament. As a result, no reform will attract universal support; the reform favoured depends to an extent on which values are prioritised over others.

This paper contends that the best option for reform is a judicial appointments commission in the form of a recommending body that supplies a shortlist of candidates to the Attorney-General. This creates a genuine check on the Attorney-General and, in doing so, enhances the perception that appointees are well-qualified and chosen based on merit. This perception will increase public confidence in the independence of the judiciary and help to protect judges from political attacks. The Attorney-General's retention of discretion and the involvement of MPs in the process enhances the democratic legitimacy of the judiciary, a particularly important feature given that judges will have the power to strike down laws passed by Parliament.

Although the present system of appointing judges has operated effectively in the current context, it is insufficiently robust to withstand the additional pressure inevitably placed upon it if a supreme law BORA were enacted. Accordingly, the adoption of a supreme law BORA should be accompanied by the creation of a judicial appointments commission in New Zealand. 
X Bibliography

A Cases

$1 \quad$ New Zealand

Ministry of Transport $v$ Noort [1992] 3 NZLR 260 (CA).

New Zealand Maori Council v Attorney-General [1987] 1 NZLR 641 (CA).

$R$ v Pora [2001] 2 NZLR 37 (CA).

$R$ v Poumako [2000] 2 NZLR 695 (CA).

2 Canada

In the Matter of a Reference by the Governor in Council concerning sections 5 and 6 of the Supreme Court Act, R.S.C. 1985, c. S-26, as set out in Order in Council P.C. 2013-1105 dated October 22, 2013 [2014] 1 SCR 433.

$R v$ Drybones [1970] SCR 282.

$R v$ Morgentaler [1988] 1 SCR 30.

$R v$ Oakes [1986] 1 SCR 103.

$R$ v Sparrow [1990] 1 SCR 1075.

Vriend v Alberta [1998] 1 SCR 493.

\section{$B$ Legislation and Bills}

$1 \quad$ New Zealand

Constitution Act 1986.

District Courts Act 1947.

Judicature Act 1908. 
Judicature Modernisation Bill 2013 (178-2).

Letters Patent Constituting the Office of Governor-General of New Zealand 2006.

New Zealand Bill of Rights Act 1990.

Oaths and Declarations Act 1957.

Supreme Court Act 2003.

Te Ture Whenua Māori (Maori Land Act) 1993.

\section{Canada}

Canadian Bill of Rights SC 1960 c 44.

Canadian Charter of Rights and Freedoms, Part I of the Constitution Act 1982, being sch B to the Canada Act 1982 (UK) c 11.

Supreme Court Act RSC 1985, c S9-26.

\section{United Kingdom}

Constitutional Reform Act 2005 (UK).

Courts and Legal Services Act 1990 (UK).

\section{Books and Chapters in Books}

James Allan Democracy in Decline: Steps in the Wrong Direction (McGill-Queen's University Press, Montreal, 2014).

James Allan "Judicial Appointments in New Zealand: If it were done when 'tis done, then 'twere well it were done openly and directly" in Kate Malleson and Peter $\mathrm{H}$ Russell (eds) Appointing Judges in an Age of Judicial Power: Critical Perspectives from around the World (University of Toronto Press, Toronto, 2006) 103. 
Andrew Butler and Petra Butler "Protecting Rights" in Caroline Morris, Jonathan Boston and Petra Butler (eds) Reconstituting the Constitution (Springer Verlag, Berlin, 2011) 157.

JF Burrows and RI Carter Statute Law in New Zealand (4th ed, LexisNexis, Wellington, 2009).

Munroe Eagles and Sharon A Manna "Politics and Government" in Patrick James and Mark Kasoff (eds) Canadian Studies in the New Millennium (University of Toronto Press, Toronto, 2008) 65.

Joseph F Fletcher and Paul Howe "Public Opinion and Canada's Courts" in Paul Howe and Peter H Russell (eds) Judicial Power and Canadian Democracy (McGill-Queen's University Press, Montreal, 2001) 255.

Martin Friedland "Appointment, discipline and removal of judges in Canada" in HP Lee (ed) Judiciaries in Comparative Perspective (Cambridge University Press, Cambridge, 2011) 46.

Ian Greene The Charter of Rights (Lorimer, Toronto, 1989).

Ian Greene The Courts (UBC Press, Vancouver, 2006).

JAG Griffith Politics of the Judiciary (5th ed, Fontana Press, London, 1997).

Lori Hausegger, Matthew Hennigar and Troy Riddell Canadian Courts (Oxford University Press, Oxford, 2009).

Vicki C Jackson "Judicial Independence: Structure, Context, Attitude" in Anja SeibertFohr (ed) Judicial Independence in Transition (Springer, Heidelberg, 2012) 19.

Phillip A Joseph "Appointment, discipline and removal of Judges in New Zealand" in HP Lee (ed) Judiciaries in Comparative Perspective (Cambridge University Press, Cambridge, 2011) 66.

Phillip A Joseph Constitutional and Administrative Law in New Zealand (4th ed, Brookers, Wellington, 2014). 
Rory Leishman Against Judicial Activism: The Decline of Freedom and Democracy in Canada (McGill-Queen's University Press, Montreal \& Kingston, 2006).

Kate Malleson "The New Judicial Appointments Commission in England and Wales: New Wine in New Bottles" in Kate Malleson and Peter H Russell (eds) Appointing Judges in an Age of Judicial Power: Critical Perspectives from around the World (University of Toronto Press, Toronto, 2006) 39.

Anthony Mason "The Appointment and Removal of Judges" in Helen Cunnningham (ed) Fragile Bastion (Judicial Commission of New South Wales, Sydney, 1997) 1.

FL Morton "Judicial Appointments in Post-Charter Canada: A System in Transition" in Kate Malleson and Peter H Russell (eds) Appointing Judges in an Age of Judicial Power: Critical Perspectives from around the World (University of Toronto Press, Toronto, 2006) 56.

FL Morton "Judicial Recruitment and Selection" in FL Morton (ed) Law, politics and the judicial process in Canada (3rd ed, University of Calgary Press, Calgary AB, 2002) 117.

Geoffrey Palmer "Judicial Selection and Accountability: Can the New Zealand System Survive?" in BD Gray and RB McClintock (eds) Courts and Policy: Checking the Balance (Brookers, Wellington, 1995) 11.

Geoffrey Palmer Reform (Victoria University Press, Wellington, 2013).

Paul Rishworth and others The New Zealand Bill of Rights (Oxford University Press, Oxford, 2003)

Kent Roach "Judges and free speech in Canada" in HP Lee (ed) Judiciaries in Comparative Perspectives (Cambridge University Press, Cambridge, 2011) 175.

Alan Paterson "The Scottish Judicial Appointments Board: New Wine in Old Bottles?" in Kate Malleson and Peter H Russell (eds) Appointing Judges in an Age of Judicial Power: Critical Perspectives from around the World (University of Toronto Press, Toronto, 2006) 13. 
Florian Sauvageau, David Schneiderman and David Taras The Last Word: Media Coverage of the Supreme Court of Canada (UBC Press, Vancouver, 2006).

Jeffrey Simpson Faultlines: Struggling for a Canadian Vision (Harper Collins, Toronto, 1993).

Lorne Sossin "Judges, bias and recusal in Canada" in HP Lee (ed) Judiciaries in Comaprative Perspective (Cambridge University Press, Cambridge, 2011) 301.

Robert Stevens The English Judges: Their Role in the Changing Constitution (Hart, Oxford, 2002).

Robert Stevens The Independence of the Judiciary - the view from the Lord Chancellor's Office (Clarendon Press, Oxford, 1993).

Jack Straw Aspects of Law Reform: An Insider's Perspective (Cambridge University Press, Cambridge, 2013).

Michael C Tolley "Legal Controversies over Federal Judicial Selection in the United States: Breaking the Cycle of Obstruction and Retribution over Judicial Appointments" in Kate Malleson and Peter H Russell (eds) Appointing Judges in an Age of Judicial Power: Critical Perspectives from around the World (University of Toronto Press, Toronto, 2006) 80.

Sophie Turenne "Judicial Independence in England and Wales" in Anja Seibert-Fohr (ed) Judicial Independence in Transition (Springer, Heidelberg, 2012) 147.

James Walker "Race," Rights and the Law in the Supreme Court of Canada (Wilfrid Laurier University Press, Waterloo, 1997).

Jacob Ziegel "Merit, Selection and Democratization of Appointments to the Supreme Court of Canada" in FL Morton (ed) Law, politics and the judicial process in Canada (3rd ed, University of Calgary Press, Calgary AB, 2002) 159.

\section{Journal Articles}

R Blake Brown "The Supreme Court of Canada and Judicial Legitimacy: The Rise and Fall of Chief Justice Lyman Poore Duff" (2002) 47 McGill LJ 559. 
Robin Cooke "Empowerment and Accountability: The Quest for Administrative Justice" (1992) 18 CLB 1326.

Richard Cornes "A Point of Stability in the Life of the Nation: The Office of the Chief Justice of New Zealand - Supreme Court Judge, Judicial Branch Leader, and Constitutional Guardian and Statesperson" [2013] NZ L Rev 549.

Lianne Dalziel "Who Judges the Judges?" [1998] NZLJ 333.

FC DeCoste "Political Corruption, Judicial Selection and the Rule of Law" (2000) 38 Alta L Rev 654.

Paul East "A Judicial Commission" [1995] NZLJ 189.

Thomas Eichelbaum "The Inaugural Neil Williamson Memorial Lecture: Judicial Independence Revisited" (1997) 6 Canterbury L Rev 421.

Simon Evans and John Williams "Appointing Australian Judges: A New Model" (2008) 30 Sydney Law Review 295.

Brian Galligan and Peter Russell "The Politicisation of the Judiciary in Australia and Canada" (1995) 67 The Australian Quarterly 85.

Nuno Garoupa and Tom Ginsburg "Guarding the Guardians: Judicial Councils and Judicial Independence" (2009) 57 The American Journal of Comparative Law 103.

Fabien Gélinas "Judicial Independence in Canada: A Critical Overview" in Anja Seiber-Fohr (ed) Judicial Independence in Transition (Springer, Heidelberg, 2012) 567.

Dyson Heydon "Judicial Activism and the Death of the Rule of Law" (2003) 47 Quadrant 9.

Janet Hiebert "New Constitutional Ideas: Can Parliamentary Models Resist Judicial Dominance When Interpreting Rights?" (2004) 82 Tex L Rev 1963.

Jack Hodder "Judicial Appointments in New Zealand" [1974] NZLJ 80. 
Peter Hogg "Appointment of Justice Marshall Rothstein to the Supreme Court of Canada" (2006) 44 Osgoode Hall LJ 527.

Peter Hogg "Appointment of Thomas A Cromwell to the Supreme Court of Canada" (2009) 47 SCLR 413.

Sundeep Iyer "The fleeting benefits of appointments commissions for judicial gender equality" (2013) 51 Commonwealth and Comparative Politics 97.

Kenneth Keith "A Bill of Rights for New Zealand: Judicial Review versus Democracy" (1985) 11 NZULR 307.

Kenneth Keith "Concerning Change: The Adoption and Implementation of the New Zealand Bill of Rights Act 1990" (2000) 31 VUWLR 721.

Kate Malleson "Creating a Judicial Appointments Commission: Which Model Works Best" [2004] Public Law 102.

Kate Malleson "Diversity in the Judiciary: The Case For Positive Action" (2009) 36 Journal of Law and Society 376.

Patrick J Monahan "The Supreme Court of Canada in the $21^{\text {st }}$ Century" [2001] The Canadian Bar Review 374.

Patrick McCabe "Appointing Judges" [2004] NZ L Rev 244.

Peter McCormick "Choosing the Chief: Duality, Seniority, and Beyond" (2013) 47 J Can Studies 5.

Peter McCormick "New Questions about an Old Concept: Supreme Court of Canada's Judicial Independence" (2004) 4 RCSP 839.

Peter McCormick "Selecting the Supremes: The Appointment of Judges to the Supreme Court of Canada" (2005) 7 J App Prac \& Process 1.

John McGrath "Appointing the Judiciary" [1998] NZLJ 314.

John McGrath "The Crown, the Parliament and the Government (Harkness Henry Lecture)" (1999) 7 Waikato Law Review 1. 
Beverly M McLachlin "The Role of the Court in the Post-Charter Era: Policy-Maker or Adjudicator?" (1990) 39 UNB LJ 43.

Beverly M McLachlin "The Charter: A New Role for the Judiciary" (1991) Alta L Rev 540.

Penelope Nevill "New Zealand: The Privy Council is replaced with a domestic Supreme Court" (2005) 3 ICON 115.

Geoffrey Palmer "The Bill of Rights After Twenty-One Years: The New Zealand Constitutional Caravan Moves On?" (2013) 11 NZJPIL 260.

Andrew P Stockley "Judicial Independence: The New Zealand Experience" (1997) 3 Austl J Legal Hist 145.

WS Tarnopolsky "The Canadian Bill of Rights From Diefenbaker to Drybones" (1971) 17 McGill LJ 437.

David L Weiden "Judicial Politicization, Ideology, and Activism at the High Courts of the United State, Canada, and Australia" (2011) 64 Political Research Quarterly 335

David Williams "The Judicial Appointment Process" [2004] NZ L Rev 39.

Margaret Wilson "Appointing Judges the New Zealand Way" (2014) 21 Waikato Law Review 41.

Margaret Wilson "From Privy Council to Supreme Court: A Rite of Passage for New Zealand's Legal System" (2010) 18 Waikato Law Review 1.

Jacob Ziegel "A New Era in the Selection of Supreme Court Judges" (2006) 44 Osgoode Hall LJ 547.

\section{E Parliamentary and Government Materials}

$1 \quad$ New Zealand

(5 December 2013) 695 NZPD 15299-15314.

A Bill of Rights for New Zealand: A White Paper [1985] AJHR A6. 
Judicature Modernisation Bill 2014 (178-2) (select committee report).

New Zealand Law Society "Submissions on the White Paper: A Bill of Rights for New Zealand" (20 December 1985).

Office of the Minister of Justice, Cabinet Social Policy Committee "Government Response to the Law Commission's Report: Review of the Judicature Act 1908: Towards a New Courts Act" (Ministry of Justice, Wellington, April 2013).

Supreme Court, Court of Appeal and High Court "Submission on the Judicature Modernisation Bill" (2014).

\section{Canada}

Department of Justice of Canada "Minister of Justice Announces Selection Process for the Supreme Court of Canada" (press release, 28 May 2008).

FL Morton "Submission to the Standing Committee on Justice and Human Rights on Reforming the Judicial Appointment Process for the Supreme Court of Canada" (1 April 2004).

Prime Minister's Office "Prime Minister announces appointment of Mr. Justice Marshall Rothstein to the Supreme Court" (press release, 1 March 2006).

\section{F Reports}

\section{$1 \quad$ New Zealand}

Advisory Group on Replacing the Privy Council A New Supreme Court (Government Printer, Wellington, 2002).

Chen Palmer \& Partners "Memorandum to the Hon Margaret Wilson, AttorneyGeneral: Judicial Administration Issues" (1 November 2002).

Law Commission Review of the Judicature Act 1908: Towards a Consolidated Courts Act (NZLC IP29, 2012).

Law Commission Review of the Judicature Act 1908: Towards a New Courts Act (NZLC R126, 2012). 
Ministry of Justice Appointing Judges: A Judicial Appointments Commission for New Zealand? (Government Printer, Wellington, 2004).

Ministry of Justice High Court judges appointment protocol (26 April 2013).

Ministry of Justice Judicial Appointments: Office of District Court Judge (August 2012).

Report of the Advisory Group on Replacing the Privy Council: A New Supreme Court (Government Printer, Wellington, 2002).

Report of the Royal Commission on the Courts (Government Printer, Wellington, 1978).

\section{Canada}

Ministry of Justice Proposal to Reform the Supreme Court of Canada Appointments Process (April 2005).

3 United Kingdom

Ministry of Justice The Governance of Britain: Judicial Appointments (2007).

Judicial Appointments Commission Annual Report and Accounts (2013/14).

\section{G Internet Materials}

Emmett Macfarlane "Why public hearings with Supreme Court nominees should mean something" Macleans (20 October 2011) <www.macleans.ca>.

\section{H Other Resources}

$1 \quad$ Speeches

Terrence Arnold "Judicial Appointments" (Speech to the New Zealand Bar Association Conference, Wellington, August 2003). 
Vernon Bogdanor "Parliament and the Judiciary: The Problem of Accountability" (Speech to the United Kingdom Public Administration Consortium, London, 9 February 2006).

Peter Hogg "Judicial Interview Process: Opening Remarks" (Speech to the Ad Hoc Committee on Supreme Court Appointment, Ottawa, 27 February 2006).

Kenneth Keith "The New Zealand Bill of Rights Experience: Lessons for Australia" (Speech to the Bill of Rights Conference, 21 June 2002).

Thomas Legg "Judicial Reform: Function, Appointment and Structure" (Speech to the Cambridge Centre for Public Law, Cambridge, 17 October 2003).

\section{Newspaper Articles}

Editorial "Selection of judges a muddled affair" The Dominion Post (online ed, 19 March 2012).

Sean Fine "Harper under pressure to review Supreme Court appointment process" Globe and Mail (online ed, 16 May 2014).

Sean Fine "Legal observers worry future judicial appointments will be done in secret" Globe and Mail (online ed, 18 September 2014).

Sean Fine "The secret short list that provoked the rift between Chief Justice and PMO" Globe and Mail (online ed, 23 May 2013).

Sean Fine "Tories tamp down Supreme Court nomination rumours" Globe and Mail (online ed, 18 June 2014).

Kim Mackrael and Sean Fine "Tories changed tack on Supreme Court appointments after Globe report" Globe and Mail (online ed, 16 September 2014).

Jacob Ziegel "Supreme Court Selection Process Needs More Thought" Globe and Mail (online ed, 1 April 2005). 


\section{Other Texts}

Hugo Cyr "The Bungling of Justice Nadon's Appointment to the Supreme Court of Canada" (University of Quebec, Montreal, 2014).

Adam Dodek "Reforming the Supreme Court Appointment Process, 2004-2014: A Ten Year Democratic Audit" (University of Ottawa, Ottawa, 2013).

Martin L Friedland A Place Apart: Judicial Independence and Accountability in Canada (Ottawa, 1995).

Graham Gee "The Politics of Judicial Appointments in Canada" in Judicial Appointments: Balancing Independence, Accountability and Legitimacy (Judicial Appointments Commission, 2010) 99.

Jeffrey Jowell "The Growing International Consensus in Favour of Independent Judicial Appointment Commissions" in Judicial Appointments: Balancing Independence, Accountability and Legitimacy (Judicial Appointments Commission, 2010) 1.

Baroness Usha Prashar "Translating Aspirations into Reality: Establishing the Judicial Appointments Commission" in Judicial Appointments: Balancing Independence, Accountability and Legitimacy (Judicial Appointments Commission, 2010) 41. 